\title{
Review \\ Central vs. Peripheral Action of Thyroid Hormone in Adaptive Thermogenesis: A Burning Topic
}

\author{
Yanis Zekri *, Frédéric Flamant and Karine Gauthier
}

check for updates

Citation: Zekri, Y.; Flamant, F.; Gauthier, K. Central vs. Peripheral Action of Thyroid Hormone in Adaptive Thermogenesis: A Burning Topic. Cells 2021, 10, 1327. https:// doi.org/10.3390/cells10061327

Academic Editors: Michelina Plateroti and Maria Sirakov

Received: 19 April 2021

Accepted: 25 May 2021

Published: 27 May 2021

Publisher's Note: MDPI stays neutral with regard to jurisdictional claims in published maps and institutional affiliations.

Copyright: (c) 2021 by the authors. Licensee MDPI, Basel, Switzerland. This article is an open access article distributed under the terms and conditions of the Creative Commons Attribution (CC BY) license (https:// creativecommons.org/licenses/by/ $4.0 /)$.
Institut de Génomique Fonctionnelle de Lyon, Univ Lyon, CNRS UMR 5242, INRAE USC 1370 École Normale Supérieure de Lyon, Université Claude Bernard Lyon 1, 46 allée d'Italie, 69007 Lyon, France; frederic.flamant@ens-lyon.fr (F.F.); karine.gauthier-vanacker@ens-lyon.fr (K.G.)

* Correspondence: yanis.zekri@ens-lyon.fr

\begin{abstract}
Thyroid hormones (TH) contribute to the control of adaptive thermogenesis, which is associated with both higher energy expenditure and lower body mass index. While it was clearly established that $\mathrm{TH}$ act directly in the target tissues to fulfill its metabolic activities, some studies have rather suggested that $\mathrm{TH}$ act in the hypothalamus to control these processes. This paradigm shift has subjected the topic to intense debates. This review aims to recapitulate how TH control adaptive thermogenesis and to what extent the brain is involved in this process. This is of crucial importance for the design of new pharmacological agents that would take advantage of the TH metabolic properties.
\end{abstract}

Keywords: thyroid hormones; thermogenesis; brown adipose tissue; browning; hypothalamus

\section{Introduction}

Obesity is an uncontrolled worldwide pandemic whose incidence has tripled during the last forty years. Given its social and economic burden as well as the abundance of its comorbidities such as diabetes, hypertension or atherosclerosis, many studies aimed at isolating pharmacological targets to prevent and fight this condition. Among the numerous therapeutic possibilities, thyroid hormones ( $\mathrm{TH}$, including thyroxine, or $\mathrm{T} 4$, and tri-iodothyronine, or T3, its more active metabolite) emerged as promising candidates. Already in 1895, Adolf Magnus Levy reported the influence of the thyroid status on the human basal metabolic rate. It was confirmed later that the level of circulating T3 is correlated with energy expenditure in humans [1,2]: hypothyroidism and hyperthyroidism are respectively associated with low and high energy expenditure but most importantly to high and low body mass index [3]. Similar effects are observed with exogenous T3 treatment in mice [4]. However, T3 cannot be used as a pharmacological agent since it also triggers tachycardia, lean mass loss and osteoporosis [5-7]. Thus, a recent intense effort has been dedicated to understanding how T3 fulfills its different metabolic activities, looking for the target tissues and the specific thyroid hormone receptors (TRs) involved. The final goal would be to identify new chemical compounds that could uncouple the metabolic benefits of T3 from its adverse effects.

The action of T3 on energy expenditure is traditionally considered to result from its local action in several metabolic tissues. However, an alternative possibility is that T3 acts in the hypothalamus, setting the sympathetic tune and stimulating the activity of distant tissues [8]. In both hypotheses, T3 acts via its binding to local TRs, either in metabolic tissue or hypothalamus of which respective importance remain controversial. It is yet crucial for the development of new pharmacological reagents which aim to stimulate $\mathrm{T} 3$ signaling in a tissue-selective manner to increase energy expenditure. 


\section{Energy Expenditure and Adipose Tissues: The Main Route for Adaptive Thermogenesis}

\subsection{Adaptive Thermogenesis as a Way to Modulate Energy Expenditure}

Energy expenditure is defined as a combination of both basal and adaptive thermogenesis [9]. Basal thermogenesis is the heat produced by a resting organism through all its basal exothermic metabolic processes. Thermoneutrality is then defined as the range of ambient temperature within which the body temperature can be maintained only relying on heat produced by the biochemical transformations occurring at basal metabolic rate [10]. In contrast, adaptive thermogenesis corresponds to the extra-heat produced by a combination of physical activity and specific responses triggered to face physiological stressors, including diet or ambient temperatures below thermoneutrality [9]. Thus, adaptive thermogenesis is a tunable component of a particular interest to increase energy expenditure. It can occur through shivering, involving the muscles, or to a greater extent through non-shivering mechanisms in which both adipose tissues and muscles contribute. The regulation of energy expenditure involves a dialogue between the autonomous nervous system and major peripheral organs such as the liver, the heart, the muscles, the white adipose tissue (WAT), and the brown adipose tissue (BAT). These peripheral organs also communicate together by releasing in the circulation several diffusible factors [11-15].

\subsection{Adipose Tissues and Muscle, the Main Actors of Adaptive Thermogenesis}

The three different types of adipose tissues are defined by their cell types composition, location, and subsequent functionality. Brown adipose tissue (BAT) is mainly composed of brown adipocytes characterized by a high mitochondrial content, generating its distinctive color, and giving this tissue a high respiration potential [16-18]. Brown adipocytes produce the uncoupling protein 1, UCP1, an inner mitochondrial membrane protein which, on activation by free fatty acids, drives the uncoupling of oxidative phosphorylation from ATP production by operating as a proton carrier (Figure 1). The lipid catabolism by brown adipocytes thus does not result in ATP production but in exothermic reactions $[19,20]$. Lipids, the main fuel of BAT thermogenesis, mainly come from brown adipocyte lipid droplets but can also be imported from circulation [21,22]. Glucose metabolism is also crucial for BAT activity as it contributes to lipogenesis to replenish lipid droplets or can be used as an alternative fuel [23-26]. However, while UCP1 was historically considered the only crucial mediator of BAT thermogenesis, recent work suggests that other mechanisms also participate to this process. For instance, adipocyte-specific deletion of the mitochondrial creatine kinase $\mathrm{b}(\mathrm{Ckb})$ markedly decreases the thermogenic response after $\beta 3$-adrenergic receptor stimulation [27]. CKB triggers ATP-dependent creatine phosphorylation, concomitantly with the activity of phosphatases that dephosphorylate it, generating a futile cycle [28]. This mechanism contributes to energy expenditure even in the presence of UCP1 [27]. It clearly highlights that there are UCP1-independent BAT thermogenic mechanisms [20,29], with more to be discovered.

On the contrary, adipocytes of the white adipose tissue (WAT) have reduced metabolic activity. They ensure lipid storage, favoring lipogenesis during calorie excess and breaking down triglycerides during energy restriction to fuel other organs' activity [30]. Thus, white adipocytes are not able of adaptive thermogenesis. However, upon prolonged cold exposure, beige adipocytes emerge in WAT depots, a process known as browning, or beiging [31,32]. Beige adipocytes express Ucp 1 [33] and other thermogenic markers [34], granting them the capacity to spend energy through thermogenesis (Figure 1).

In humans, BAT is mainly found in infants. In adults, browning can take place under certain conditions within specific WAT depots, particularly in the abdominal, paraspinal, supraclavicular and cervical regions [35]. Transcriptome analyses confirmed that these Ucp 1 expressing cells are more closely related to rodent beige adipocytes than to brown adipocytes [36,37]. Browning in adults can be triggered [38-41], which could be promising in the treatment of obesity. However, the significance of beige fat contribution on energy expenditure is still a matter of debate [42-44]. 


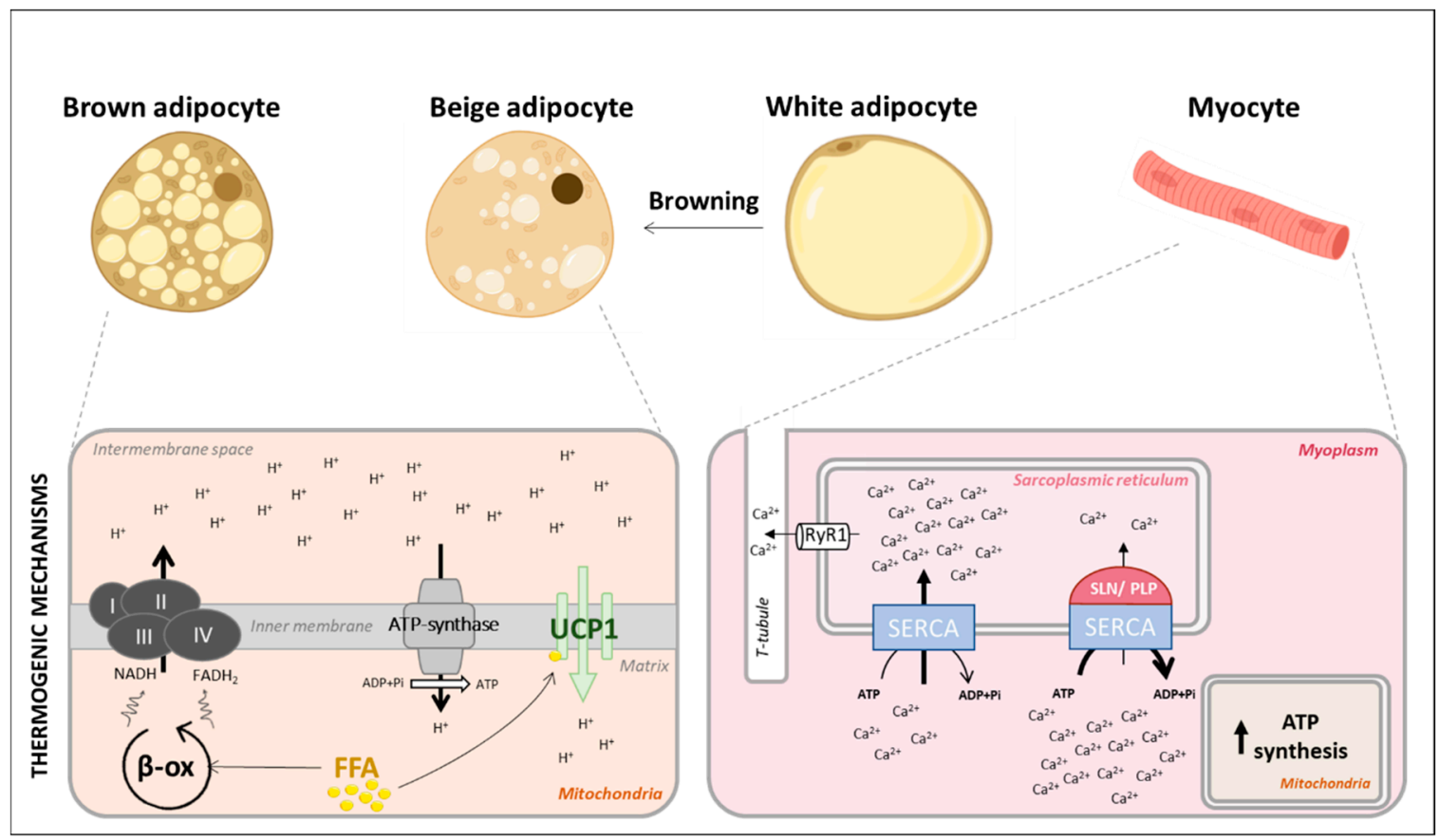

Figure 1. The main actors of adaptive thermogenesis and their principle thermogenic mechanisms. Adipose tissues and muscles are the main actors of adaptive thermogenesis. White adipocytes are not thermogenic per se but can undergo browning to generate beige adipocytes. Bottom left panel: Brown and beige adipocytes use free fatty acids (FFA) to fuel the mitochondrial $\beta$-oxidation. $\beta$-oxidation generates reduced compounds $\left(\mathrm{NADH}, \mathrm{FADH}_{2}\right)$ whose oxidation is used by the respiratory electron transport chain (complex I, II, III, IV) to pump protons $\left(\mathrm{H}^{+}\right)$into the intermembrane space. Thus, an electrochemical gradient is created and used by ATP synthase to produce ATP. UCP1 is present in the inner mitochondrial membrane and activated by FFA. UCP1 acts as a proton channel to dissipate the electrochemical gradient without producing ATP. Thus, to match the inefficient ATP production, the metabolism must increase and heat is produced. Bottom right panel: Myocytes express SERCA that is located in the sarcoplasmic reticulum (SR) membrane. SERCA transfers calcium $\left(\mathrm{Ca}^{2+}\right)$ from the cytosol to SR lumen using ATP hydrolysis. The calcium gradient generated by SERCA is dissipated by ryanodine receptor (RyR1). SERCA transport activity can be inhibited by two peptides: phospholamban (PLP) or sarcolipin (SLN), but its ATPase activity remains. To match $\mathrm{Ca}^{2+}$ transport, ATP mitochondrial synthesis increases and heat is produced.

Muscle is also a thermogenic organ. It increases energy expenditure by inducing the sarcoplasmic and endoplasmic $\mathrm{Ca}^{2+}$-dependent ATPase (SERCA) that breaks down ATP to transport $\mathrm{Ca}^{2+}$ from cytosol to reticulum lumen. SERCA activity is regulated by two peptides that uncouple $\mathrm{Ca}^{2+}$ transport to ATP breakdown (Figure 1), generating a futile cycle and ultimately heat production [45-48]. Muscle cells also produce UCP3, an UCP1related protein which uncoupling capacity remains unclear $[49,50]$. As skeletal muscle is reckoned to represent as around $40 \%$ of the total body mass, we can expect that only minor changes in its non-shivering thermogenesis could largely contribute to whole-body thermogenesis and energy expenditure.

\subsection{Adaptive Thermogenesis Is Induced by Cold Exposure and High Fat Diet}

Adaptive thermogenesis can be triggered by two natural drivers: cold exposure [16,51] that increases the demand of heat production to maintain the body temperature, and high fat diet [52-55] that stimulates the elimination of excessive calories. Cold is sensed by thermoreceptors in the cutaneous terminals of primary somatosensory neurons $[56,57]$. High fat diet signaling likely involves the cholecystokinin release from endocrine cells of the small intestine, which triggers excitation of gut vagal afferents [58,59]. In both cases, the stress signal is integrated by the hypothalamus that rapidly triggers the release of norepinephrine (NE) from the nerve terminals of the sympathetic nervous system (SNS) innervating the BAT, and stimulating the $\beta$-adrenergic receptors present at the surface 
of the adipocytes. The signal is then relayed intracellularly by the cAMP-dependent protein kinase A (Figure 2) [16]. Additionally, while cold exposure provokes WAT browning $[26,60,61]$, the effects of high fat diet on this process are still conflicting [62,63]. As expected, the concomitant knock-out of the $3 \beta$-adrenergic receptors ( $\beta$-AR) leads to cold hypersensitivity [64] and to an increased sensitivity to diet-induced obesity at thermoneutrality [65]. A similar phenotype is observed in Ucp1KO mice [66,67], which historically designated UCP1 as the only crucial mediator of BAT thermogenesis. However, Ucp $1 K O$ animals display altered mitochondrial respiration and are more susceptible to reactive oxygen species [68]. In the absence of functional mitochondria, any UCP1-independent mechanism involving mitochondria would not be efficient in the Ucp $1 \mathrm{KO}$ mice and thus difficult to unravel. Thus, the below-mentioned papers mainly concluding on the role of UCP1 should not be overinterpreted. Some other mechanisms might be involved, as previously mentioned for creatine futile cycles [27,28].

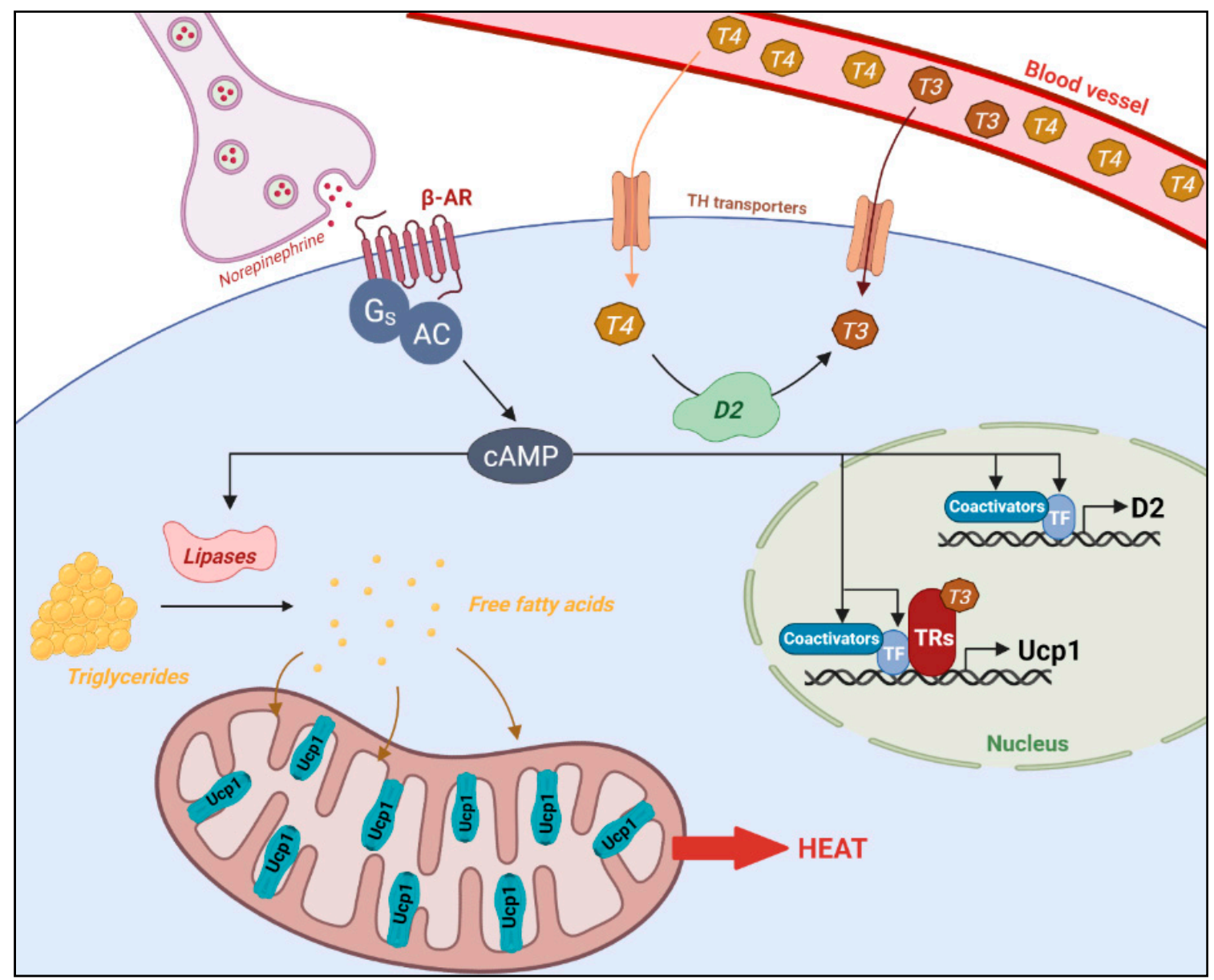

Figure 2. Control of brown adipocyte UCP1-dependent thermogenesis by norepinephrine and thyroid hormone. Sympathetic neurons release synaptic norepinephrine that binds to $\beta$-adrenergic receptors $(\beta-A R)$ coupled to stimulatory guanine nucleotide binding protein (Gs) which activates adenylate cyclase (AC) to produce cAMP. This adrenergic signaling activates transcription factors (TF) and coactivators involved in the regulation of $D 2$. Both adrenergic signaling and thyroid hormone receptors (TRs) regulate Ucp1 expression. Triglycerides are broken down into free fatty acids by lipases and transported to mitochondria to fuel the $\beta$-oxidation and activate UCP1. UCP1 uncouples ATP production from respiration, requiring an increased mitochondrial activity and heat is produced.

Interestingly, thyroid hormones status alters the thermogenesis in response to both cold [69-71] and high fat diet [72], pointing out that they are a crucial component when it comes to regulate energy expenditure and adaptive thermogenesis. 


\section{T3, an Important Component of Energy Expenditure}

The thyroid gland mainly produces $\mathrm{T} 4$, the inactive form of thyroid hormone, which is converted to active T3 by deiodination in other organs [73]. While the serum levels of T4 and $\mathrm{T} 3$ are normally maintained in a narrow range, local deiodination can increase the T3 level by the type 2 deiodinase (D2) in different organs. T3 signaling is mediated by nuclear receptors TR $\alpha 1, T R \beta 1$ and TR $\beta 2$ (collectively TRs) produced by Thra and Thrb, two genes which are expressed in many cell types $[74,75]$. These receptors are bound to specific DNA sequences and either repress or activate the transcription of neighboring genes depending on T3 binding [76-78].

\subsection{T3 Signaling Is Necessary for Cold-Induced Thermogenesis}

D2 is expressed in BAT (Figure 2) and its activity can be locally induced upon cold exposure [79], triggering within a few hours a fivefold increase in the local concentration of T3 [80]. It leads to an increased TR activity within $24 \mathrm{~h}$ [81]. Accordingly, D2KO mice that lack D2 activity [82], are more sensitive to cold than WT mice, losing more weight and failing in efficiently defend their core body temperature when placed at $4{ }^{\circ} \mathrm{C}$ [83]. Their BAT does not fully respond to SNS stimulation. Importantly, brown adipocytes isolated from $\mathrm{D} 2 \mathrm{KO}$ mice also fail to efficiently increase oxygen consumption and cAMP accumulation upon norepinephrine stimulation. Therefore, $\beta$-AR sensitivity is highly dependent on T3 produced in BAT. Moreover, the dysfunctional adaptive thermogenesis observed in vivo is not due to a lack of UCP1 activation or a defective lipolysis, but from impaired lipogenesis, which disrupts the restoration of BAT lipids [84]. To compensate for the altered thermogenesis, D2KO mice mount an exaggerated SNS response below thermoneutrality. The permanent stimulation of BAT leads to an overexpression of the Ucp 1 gene and to an increased lipolysis. The unopposed and persistent stimulation in absence of lipogenesis results in the exhaustion of the free fatty acids storage in brown adipocytes, preventing an efficient BAT thermogenesis and ultimately leading to hypothermia. This suggests that in addition to increasing the sensitivity of BAT to $\beta-A R, T 3$ also induces lipogenesis in brown adipocytes.

\subsection{The Role of T3 Signaling in Response to Diet-Induced Obesity}

Thermogenesis is also triggered by an excess of circulating lipids after a high fat diet. The role of $\mathrm{T} 3$ signaling in this process is less documented. At $23{ }^{\circ} \mathrm{C}, \mathrm{D} 2 \mathrm{KO}$ mice develop obesity similarly to control in response to a high fat diet [85]. As $23^{\circ} \mathrm{C}$ is below thermoneutrality and represents a mild cold stress [86], the SNS outflow increases to raise energy expenditure, independently of T3. As mentioned above, in D2KO mice, this activation is even higher to bypass a decrease in SNS sensitivity. Thus, it prevents obesity despite a lack of D2. However, $\mathrm{D} 2 \mathrm{KO}$ mice become hypersensitive to obesity at $30^{\circ} \mathrm{C}$ [85], a temperature at which SNS does not stimulate BAT thermogenesis. Consequently, there is no compensation for the lack of local T3 that must be needed in these conditions to increase energy expenditure and limit weight gain. This is accompanied by a blunted response of Ucp 1 expression in the BAT [85]. This suggests that a local increase of T3 catalyzed by D2 is important to increase energy expenditure in BAT after a high fat diet. Mice KO for A-FABP, an adipokine fatty acid-binding protein, fail to induce D2 expression in the BAT. Subsequently, these mice cannot respond to either cold or high fat diet [87], supporting the crucial role of $\mathrm{T} 3$ in these two responses.

\subsection{Tissue-Selective Metabolic Action for T3 Signaling}

The different studies cited and analyzed above clearly establish that T3 signaling is critical to trigger adaptive thermogenesis both in response to cold and to a high fat diet and that D2 up-regulation in BAT is likely to be involved in both cases. D2 is expressed in the BAT [88] but also in myotubes [89-91]. To address the respective contribution of adipocytes and muscle fibers in energy metabolism, tissue-selective knock-out $(\mathrm{KO})$ were performed. The consequences of inactivating D2 from Fabp4-expressing white and brown adipocytes 
(FAT-D2KO) or Myosin light-chain $1 f$-expressing skeletal muscle fibers (SM-D2KO) have been compared to a general $\mathrm{KO}$ of this enzyme (GLOB-D2KO) [92].

$S M-D 2 K O$ mice do respond normally to cold or high fat diet. This suggests a negligible contribution of T3 produced in myotubes to adaptive thermogenesis. Absence of D2 would rather lead to changes in muscle contractile functions and fiber type composition [93].

Unlike GLOB-D2KO mice, FAT-D2KO mice are hypersensitive to diet-induced obesity at $23{ }^{\circ} \mathrm{C}$. FAT-D2KO mice have a reduced contribution of fatty acids to energy expenditure and mainly use glucose as a source of energy. This phenotype indicates that locally produced $\mathrm{T} 3$ accelerates fatty acids oxidation in BAT, a process required for BAT activation and optimal Ucp1 expression/activity [94]. It can be hypothesized that the increase in glucose oxidation in FAT-D2KO mice is a compensation for the altered fatty acids oxidation, but does not produce as much heat in response to a high fat diet [95]. Altered fatty acids oxidation could therefore explain the higher weight gain.

\subsection{TR Isoform Selective Regulation of Adaptive Thermogenesis}

Many mice models with knock-out (KO) or knock-in (KI) mutations of TRs have been generated [96] to elicit the role of T3 action and the TR isoform specificity on energy expenditure and thermogenesis. Thra/Thrb $\mathrm{KO}$ mice, devoid of all receptors, have a lower body temperature at thermoneutrality $[97,98]$ and fail to defend their temperature when exposed to cold [98]. Thra KO mice, whose TR $\alpha 1$-expressing locus is deleted [97], also display a limited capacity for adaptive thermogenesis and display a profound hypothermia at $4{ }^{\circ} \mathrm{C}$ [99]. However, Ucp 1 expression is not down-regulated in Thra $\mathrm{KO}$ mice. This suggests that TR $\alpha 1$ function is not directly linked to the transcriptional regulation of Ucp1. Brown adipocytes cultivated from Thra $\mathrm{KO}$ mice do not respond to norepinephrine stimulation by an increased oxygen consumption, but the response of Ucp 1 and D2 is maintained. KI mice, heterozygous for a dominant-negative mutated form of TR $\beta 1$ that cannot bind T3 [100], also have a defective thermogenesis but characterized by a reduction of Ucp1 level and heat production during norepinephrine infusion [101]. Importantly, while isolated adipocytes from hypothyroid mice supplemented with T3 can induce cAMP production (reflecting the adrenergic responsiveness), they do not when supplemented with GC-1 [101], a selective TR $\beta$ agonist [102]. This emphasizes the importance of TR $\alpha 1$ in the brown adipocytes response. Altogether, the data suggest that the two receptors account for a specific subset of thermogenic function: TR $\beta 1$ is rather involved in the T3 regulation of Ucp 1 in BAT while TR $\alpha 1$ accounts for the sympathetic nervous system sensitivity.

\section{Central T3 Can Trigger Adaptive Thermogenesis: The Still Controversial Role of the Brain}

\subsection{Role of Central T3 in the Activation of BAT Thermogenesis}

Based on the aforementioned role of BAT and the importance of $D 2$ expression and activity in this tissue, the classical view was that the thermogenic effect of T4/T3 mainly involves their direct action in the BAT (Figure 3). However, as early as in 1997, some authors already hypothesized that the thermal setpoint was centrally regulated and the effect of hyperthyroidism on BAT was the consequence of hyperthyroidism in the brain [103]. It was already known that electrical stimulation of the ventromedial hypothalamus (VMH) increases BAT temperature while VMH lesions inhibit thermogenesis [104,105]. As TRs and $\mathrm{TH}$ transporters are expressed in the $\mathrm{VMH}, \mathrm{TH}$ signaling might be important in this brain area for the regulation of peripheral metabolism [106-108]. In 2010, Lopez et al. brought clear evidence that injection of $\mathrm{T} 3$ in $\mathrm{VMH}$, but not in other hypothalamic nuclei, triggers a thermogenic response in BAT, an increase in energy expenditure and a subsequent weight loss without affecting food intake [8]. This treatment reduces hypothalamic AMPK $\alpha$ phosphorylation in the $\mathrm{VMH}$, which in turn induces the SNS/ $\beta$-AR system and activates the BAT (Figure 3), an effect that depends on TRs expression in the VMH. Both TR $\alpha$ and $\mathrm{TR} \beta$ are present in the VMH; however, VMH-specific deletion of TR $\beta$ does not alter Ucp 1 
BAT expression [109], suggesting that TR $\alpha$ in the VMH is the main contributor for the T3 centrally mediated BAT activation.

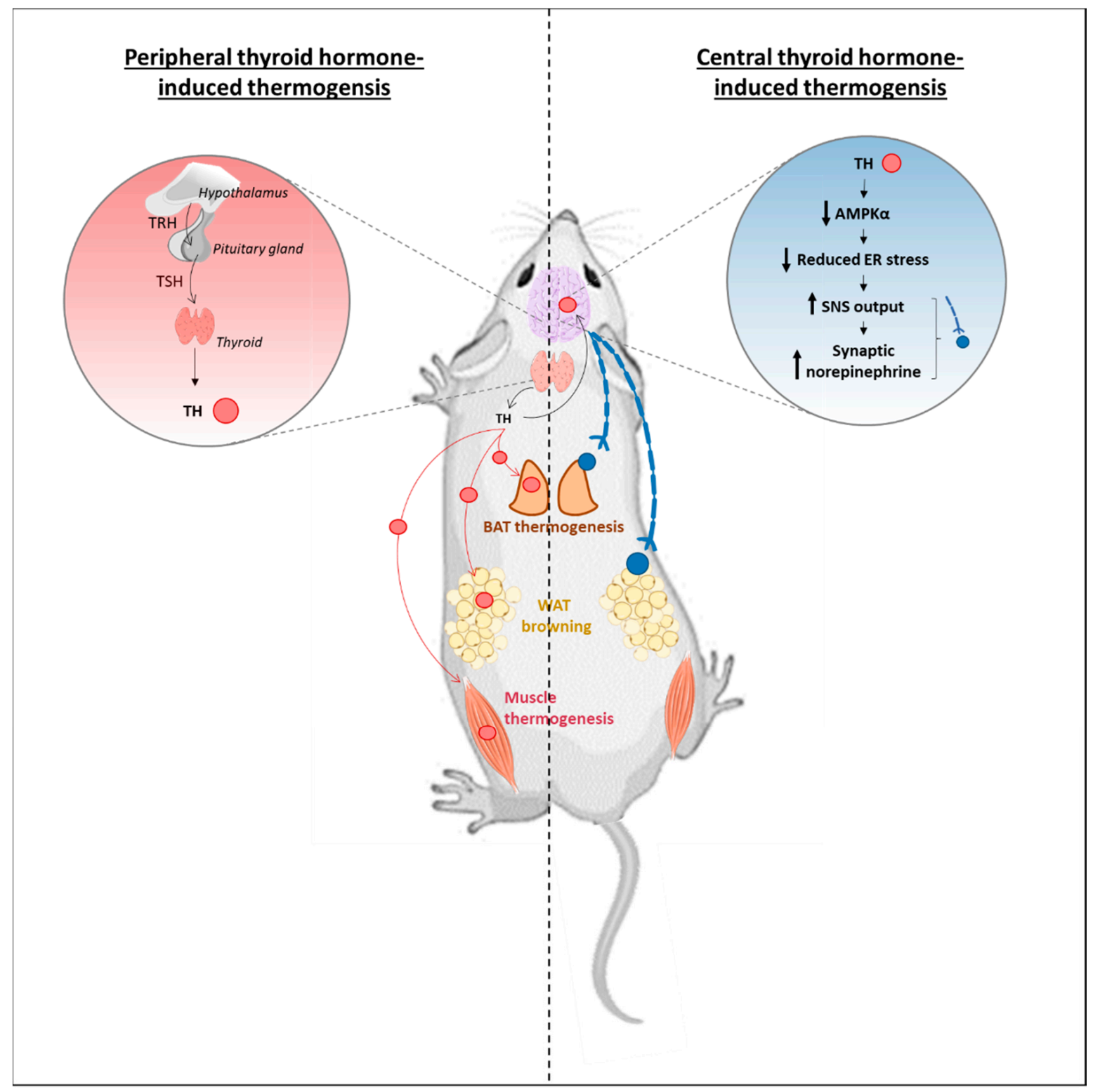

Figure 3. The different views for TH-induced adaptive thermogenesis. In the classical «peripheral » view (left panel), TH (red dots) are produced by the hypothalamic-pituitary-thyroid axis. TH are then released in the blood (red arrows) and are transported to targeted tissues. Then, they locally act on their receptors to trigger BAT and muscle thermogenesis, as well as WAT browning. This paradigm has been challenged by the description of a central mode of TH action to trigger adaptive thermogenesis (right panel). In this view, TH reaching the ventromedial medial hypothalamus decreases AMPK $\alpha$ phosphorylation in this region, alleviating endoplasmic reticulum (ER) stress. It leads to an increased sympathetic nervous system (SNS) output (axons drawn in blue) and the release of synaptic norepinephrine (blue dots) to trigger both BAT thermogenesis and WAT browning. However, no evidence as so far been brought to consider a TH-central control of muscle adaptive thermogenesis.

Regulation of hypothalamic AMPK $\alpha$ activity to stimulate SNS and BAT thermogenesis has already been described for several hypothalamic peptides and hormones, including Bmp8b [110], Glp1 [111], estradiol [112] or leptin [113]. Recent work suggests that reduced AMPK $\alpha$ lowers endoplasmic reticulum stress in the hypothalamus [114] which in return facilitates BAT thermogenesis [115]. It is conceivable that central T3 uses this pathway to 
trigger its metabolic effects. However, the precise molecular mechanisms hidden behind remain unknown.

Despite raising new possibilities and a fresher view for T3 mode of action, such studies are nevertheless controversial. Indeed, the implantation of bee wax pellets containing T3 in the VMH [116] does not reproduce the thermogenic response observed after VMH T3 injection [117]. In addition, T3 injected in the blood triggers a thermogenic response even in $\beta$-AR triple $\mathrm{KO}$ mice [118], arguing against a possible involvement of a SNS input to the BAT. ASTRO-D2KO mice that lack D2 expression in Gfap-expressing astrocytes, display an increased BAT activity and an accelerated fatty acid oxidation [92]. As astrocytes are the only T3-producing cells in the brain [119], it emphasizes a role for central T3 in BAT activity. However, these observations are at odd with Lopez et al. conclusions [8] as it suggests that central T3 does not stimulate but rather slows down BAT thermogenesis.

Interestingly, the thermogenic effects of injecting $\mathrm{T} 3$ in the $\mathrm{VMH}$ are observed in mice first exposed at $18{ }^{\circ} \mathrm{C}$ to recruit the BAT and then acclimated at $30{ }^{\circ} \mathrm{C}$ [8]. On the contrary, mice implanted with bee wax pellets, where no thermogenic effect of central $\mathrm{T} 3$ is observed, are kept at $23^{\circ} \mathrm{C}$. Yet, temperature is determinant when looking at BAT activity. As mentioned before, room temperature represents a mild cold stress exposure and activates BAT whereas thermoneutrality is obtained at $30{ }^{\circ} \mathrm{C}$. In experiments using bee wax pellets, housing mice at $23{ }^{\circ} \mathrm{C}$ could constitutively activate BAT thermogenesis thus preventing any visible effect of central T3 on this process.

\subsection{The Promising Metabolic Effects of WAT Browning: Also Concerned by a Central T3 Control?}

In mice, browning can be triggered by three different mechanisms: (1) recruitment and activation of immune cells in WAT delivering norepinephrine locally [120], (2) direct action of hormones on white adipocytes, (3) SNS activation of the WAT. Some convincing elements have linked T3 to the two latter mechanisms.

Rodents treatment with GC-1, a TR- $\beta$ agonist, induces browning of subcutaneous WAT, increases energy expenditure, oxygen consumption, food intake and adiposity in both WT [121] and $o b / o b$ obese mice [122]. GC-1 also reduces BAT activity, as testified by the decrease in $U c p 1$ expression and the lower $\left[{ }^{18} \mathrm{~F}\right]-F D G$ uptake in this tissue, which suggests that BAT is not responsible for the observed effects. Recently, Johann et al. showed that T3-induced WAT browning is neither associated with norepinephrine nor cAMP increase in the inguinal WAT. Moreover, browning is still observed at thermoneutrality, i.e., when the WAT is functionally denervated [123]. This is confirmed by the in vitro browning of primary white adipocytes treated with GC-1 [122]. This suggests that T3 induces browning through a peripheral mechanism.

However, like BAT activity, WAT browning might also be sensitive to a central action of T3. T3 injection in the VMH, but not other brain regions, triggers WAT browning via the same AMPK-dependent pathway described for T3 mediated activation of the BAT [124]. These results reinforce other observations where T3 centrally administered by osmotic minipumps also increases WAT browning [125]. This common activation for both BAT and WAT could find its origin in shared neuronal pathways for BAT and WAT innervation [126,127].

Paradoxically, WAT browning is also observed in hypothyroid mice [128]. This is concomitant to a decrease in BAT activity despite a paradoxical high expression of thermogenic genes and norepinephrine concentration in this tissue. This likely points out to a primary defect in BAT thermogenesis, compensated by an increased sympathetic outflow to both BAT and WAT. A similar observation was already made in previous cold exposure studies [83,84].

Browning has raised many therapeutic interests in recent years, especially since beige adipocytes are a main site of adaptive thermogenesis in humans after cold exposure [40] and administration of $\beta 3$-adrenergic receptor agonists $[39,129]$. Some results indicate that T3 might also potentiate browning in humans. First, D2 allowing conversion from T4 to T3, is expressed and active in human preadipocytes from both mesenteric and subcutaneous 
adipose tissues [130]. In addition, T3 also induces Ucp1 expression, mitogenesis and oxygen consumption in a TR $\beta$-dependent manner in vitro in multipotent adipose-derived stem cells [131]. In agreement, T3 has also recently been shown to induce Ucp1 expression and reduce lipid accumulation in human white adipocytes [132]. This is in line with the observation that $\mathrm{T} 4$ serum levels in healthy subject correlates with Ucp 1 expression in WAT [124]. Taken together, these observations suggest that the T3 effect on human WAT browning might participate in the thermogenic response orchestrated by T3 injection.

In addition, the thermogenic and metabolic responses to T3 are also observed in Ucp1KO animals $[123,133]$. This persistent response suggests that T3 triggers UCP1independent thermogenic processes in brown/beige adipose tissues. It seems however that known mechanisms such as calcium and creatine are not inducible by T3 $[28,134,135]$. An alternative would be that T3-mediated thermogenic effects could also involve other tissues.

\subsection{Muscle: Another Thermogenic Actor, Same Conflict?}

Interestingly, it was observed that T3-mediated increase in body temperature in Ucp $1 K O$ mice is associated with a higher lipid uptake and a decrease in glycogen content in muscles [123]. In humans, increased TH levels trigger a higher glucose uptake in skeletal muscle than in BAT and WAT [136]. Increased metabolic rate is also noticed in the muscle of patients with THRB mutations that have high circulating levels of T4 and T3 [137]. As TR $\alpha 1$ is highly expressed in muscles [75], T3 might directly stimulates T3 responsive genes expression in this tissue.

Accordingly, T3 may increase muscle metabolic response. This has been assessed in a mouse model carrying a dominant-negative mutant TR $\alpha 1$ in $\alpha$-skeletal actin-expressing cells [138], restricting the mutation to skeletal muscle and no other tissues [139]. This mutated form of TR $\alpha 1$ cannot recruit co-activators, preventing the T3-induced transcriptional response [140]. As expected, the increase of energy expenditure usually triggered by T3 is blunted in these mutant mice [138]. Muscles from mutants also display lower respiratory capacities ex vivo following T3 treatment. More surprisingly, unchallenged mutant mice display a paradoxical 5-fold increase of the muscle content in sarcolipin. This protein interacts with SERCA [141] to favor $\mathrm{Ca}^{2+}$ uncoupling from ATP hydrolysis (Figure 1), and thus contributes to the non-shivering thermogenesis in skeletal muscle [142]. The sarcolipin excess might thus represent a compensation for inadequate T3 response of the muscle thermogenesis. Neither muscle-specific deletion of D2 nor TR $\alpha 1$ dominantnegative expression alters energy expenditure or weight gain under high fat diet compared to littermate controls $[92,138,143]$. Collectively, it suggests that under a physiological stress, $\mathrm{T} 3$ in muscle might not be critical for its thermogenic action. It rather seems crucial for the response to pharmacological doses of T3. Finally, T3 intracerebroventricular injections does not induce thermogenic markers in muscle, reinforcing the idea that there is no indirect activation via the SNS [8] and that the metabolic effects mediated by T3 in muscle involve a local action.

\section{Roles for T3 Central Action in Regulating Other SNS-Sensitive Mechanisms?}

T3 and $\beta$-adrenergic signaling also regulate a common set of other physiological parameters. Following Lopez et al. observations [8], the question arose whether some of these SNS-sensitive mechanisms, which are not directly related to thermogenesis, could be regulated via a central action of $\mathrm{T} 3$.

\subsection{T3 Regulation of Glucose Homeostasis Is a Composite Process}

Hypothyroidism is associated with a reduction in glucose uptake leading to peripheral insulin resistance, while hyperthyroidism increases hepatic gluconeogenesis and thus glycemia [144-146]. At least part of these effects is mediated through the direct binding of T3 on TR $\beta$ in the promoters of target genes [144,147].

As for BAT thermogenic action of T3, some evidence suggest that T3 central action could also be involved in regulating glucose metabolism. Indeed, mild hyperthyroidism 
increases glycemia and sympathetic liver denervation slightly prevents it. It suggests that the peripheral effects outweighed the central ones: central-T3 would rather fine-tuned the glucose production rather than hold the leadership. However, parasympathetic liver denervation worsens insulin resistance during T4 administration [148]. Work from the same group shows that T3 injection in the hypothalamic paraventricular nucleus (PVN) rapidly triggers endogenous glucose production without affecting circulating $\mathrm{T} 3$, an effect blunted after sympathetic denervation [149]. However, chronic PVN administration of T3 using bee wax pellets fails to recapitulate this effect as it did for BAT thermogenesis [117]. Collectively, these data argue for at least an involvement of central T3 in the regulation of glucose homeostasis.

\subsection{T3 Regulation of Heart Rate and Hypertrophy}

Heart rate is regulated by both T3 and the $\beta$-AR system. However, T3 cardiac action does not require $\beta$-AR since the T3-induced tachycardia and cardiac hypertrophy is intact in $\beta$-AR triple KO [118]. Moreover, many cardiac genes are directly regulated by T3 [150] and possess bona fide TR response element in their promoters [151]. This is in line with heart-specific D2 overexpression that leads to tachycardia [152]. Finally, TR $\alpha 1^{+/ \mathrm{m}}$ mice that express a mutant TR $\alpha 1$ with 10-fold reduced affinity to T3 [153], have a lower heart rate despite presenting hyperstimulation of the SNS [154].

Only few elements could indicate a central T3 control of heart processes. Indeed, Goldman et al. showed twenty years ago that short term intracerebral injection of T3 could stimulate heart rate [155]. Similarly, heart-specific D2 overexpression fails to induce hypertrophy, suggesting a different mode of T3 control than for heart rate [152].

Collectively, these results argue mainly for a local, SNS-independent role of T3 in the heart. TR $\alpha 1$ is certainly the main mediator of this effect as it is the main isoform present in this tissue $[75,156]$. TR $\beta$ PV mutants that cannot bind T3, have shown to decrease heart rate and contractility, but without displaying mRNA changes [157].

\section{Selective Mice Models and Pharmacology: New Perspectives to Better Understand and Take Advantage of T3 Metabolic Effects}

\subsection{Requirements for Elaborated Transgenic Models}

Many effects mediated by T3 on adaptive thermogenesis have been deduced from the phenotype of transgenic mice models, mainly mutated for TRs and deiodinases. However, these results should be considered with caution due to these models' spatiotemporal limitations. First, most of these models exhibit the mutations without tissue specificity, while deiodinases and TRs are widely expressed $[75,158]$. Thus, when the phenotype of a particular tissue is observed, it should be taken into consideration that it may indirectly results from alterations in other tissues reached by the mutation. In that respect, Crelox system became increasingly important to investigate the role of genes in a specific tissue/cell type [159]. For instance, tissue-specific deletion of D2 has allowed to allocate the effects observed in GLOB-D2KO mice on lipid metabolism [85] to both astrocytes and BAT, but not muscle [92].

Secondly, most of these models harbor mutations from early stages of development while TH are crucial for many developmental processes [160-162]. Thus, the observations made on these models are limited as we cannot distinguish functional from developmental alterations. Notably, D2KO embryos have an altered BAT adipogenesis as well as thermogenic markers expression [163]. Thus, altered adaptive thermogenesis observed in the $\mathrm{D} 2 \mathrm{KO}$ adults could stem from an inappropriate BAT maturation. It could be explained by the crucial role of T3 for the induction of lipogenesis [164], a process required for BAT growth [165]. In that respect, inducible models [166] allow triggering mutations at adult stages and therefore free observations from putative developmental defects.

It is thus of a particular interest to combine both Cre-lox and inducible systems [159]. For instance, specific promoter-induced expression of Cre recombinase fused to the ligand binding domain of the human estrogen receptor, allow locally triggering mutations after 
tamoxifen injections [167]. Extending this to TRs or D2 will allow spatio-temporally controlling their mutations, triggering them at adult stages in the tissues of interest such as BAT, WAT muscle and brain. In this way, it will be possible to extract from the observations the very essence of $\mathrm{T} 3$ role in adaptive thermogenesis in each of the concerned tissues.

\subsection{Potential Therapeutical Applications: The Hope Raised by a New Class of Compounds}

Given the beneficial metabolic effects of T3, including lowering serum cholesterol and its potentiation of energy expenditure, T3 has been considered to be a potential drug target to fight metabolic diseases. However, its use is precluded by its advert effects, particularly in heart. A lot of efforts have been dedicated to design molecules to target TR $\beta$ and more precisely its liver action to fight hypercholesterolemia, because $\operatorname{TR} \beta$ seems to have only a minor action in heart. Several TR $\beta$ agonists have been obtained, efficient to decrease serum cholesterol but all failed in clinical trials due to off target effects, as previously reviewed [168].

A breakthrough has been made by coupling T3 to incretins to target it to specific cell types [169]. The incretins are small peptides that bind to specific transmembrane receptors, allowing them to be selectively targeted to the cells expressing the receptor. After reaching the cells, incretins trigger a cascade of phosphorylation intracellularly [170].

This principle has been applied with glucagon coupled to T3 (Glc-T3 compound) [171]. This compound mainly targets the liver and in a lesser extent the WAT, due to the expression pattern of the glucagon receptor [172]. By doing so, it lowers cholesterol, increases fatty acid oxidation, and triggers WAT browning. Short term treatment protects from atherosclerosis, nonalcoholic steatohepatitis, and limits obesity in mice models of these diseases. Synchronized signaling driven by glucagon and T3 reciprocally minimizes the inherent harmful effects of each hormone. Indeed, liver-directed T3 action offsets the diabetogenic liability of glucagon, and glucagon-mediated delivery spares the cardiovascular system from adverse T3 action. To date, that is the best compound using selective T3 activity.

Taking advantage of this concept targeting T3 to BAT or hypothalamus would be of a great interest in the context of thermogenesis, provided to find incretin receptors specifically expressed in these tissues. In this way, metabolic benefits of T3-mediated thermogenesis could be reached while bypassing the undesired effects of thyroid hormone administration [5-7].

\section{Conclusions}

The discovery of Lopez et al. concerning the central mode action of T3 [8] that could recapitulate some of its metabolic effects called into question what was previously thought. However, looking at the general picture, it appears that local should not be opposed to central, as the two modes of action seem to complement one another. The general effect observed under hyperthyroidism effect is most likely a combination of both. With the progresses made in generating specific mice model, including inducible tissue-selective mutations, new evidence should emerge shortly to clarify the debate. Meanwhile, the precise molecular mechanisms by which $\mathrm{T} 3$ regulates adaptive thermogenesis remain unclear and the emergence of these innovative mice models should help to elucidate the situation. This is of a particular interest as thyroid hormones or their agonists harbor a great metabolic potential when freed of their adverse effects. Understanding how and in which tissues thyroid hormones act should enable identifying new levers to potentiate their metabolic effects and take part in the fight against obesity and metabolic disorders.

Although the transgenic murine models and their future improvement are the cornerstone to decipher T3-mediated effects on adaptive thermogenesis, it must be remembered that these data should be carefully extrapolated to humans. Indeed, there are significant differences in the physiological regulation of thermal homeostasis in the two species. Notably, wearing clothes and living in heat regulated house keep humans closer to thermoneutrality. In sharp contrast, most of the evidence derived from mice have been obtained at room 
temperature, below thermoneutrality. In this respect, one way to "humanize" mice thermal homeostasis would be to systematically perform mice experiments at thermoneutrality. In this way, the observations would be closer to human physiology and more likely to participate in developing human strategies to counter obesity through adaptive thermogenesis.

Author Contributions: Conceptualization, K.G. and Y.Z.; writing-original draft preparation, K.G. and Y.Z.; writing - review and editing, K.G., Y.Z. and F.F.; supervision, K.G. and F.F. All authors have read and agreed to the published version of the manuscript.

Funding: This work is supported by INRAE and the European Union's H2020 research and innovation program under grant agreement $464 \mathrm{~N}^{\circ} 825753$ (ERGO).

Conflicts of Interest: The authors declare no conflict of interest.

\section{References}

1. Danforth, E.; Burger, A. The Role of Thyroid Hormones in the Control of Energy Expenditure. Clin. Endocrinol. Metab. 1984, 13, 581-595. [CrossRef]

2. Yavuz, S.; Salgado Nunez del Prado, S.; Celi, F.S. Thyroid Hormone Action and Energy Expenditure. J. Endocr. Soc. 2019, 3, 1345-1356. [CrossRef]

3. Abdi, H.; Kazemian, E.; Gharibzadeh, S.; Amouzegar, A.; Mehran, L.; Tohidi, M.; Rashvandi, Z.; Azizi, F. Association between Thyroid Function and Body Mass Index: A 10-Year Follow-Up. Ann. Nutr. Metab. 2017, 70, 338-345. [CrossRef]

4. Weiss, R.E.; Murata, Y.; Cua, K.; Hayashi, Y.; Seo, H.; Refetoff, S. Thyroid Hormone Action on Liver, Heart, and Energy Expenditure in Thyroid Hormone Receptor Beta-Deficient Mice. Endocrinology 1998, 139, 4945-4952. [CrossRef]

5. Nordyke, R.A.; Gilbert, F.I., Jr.; Harada, A.S.M. Graves' Disease: Influence of Age on Clinical Findings. Arch. Intern. Med. 1988, 148, 626-631. [CrossRef] [PubMed]

6. Liu, G.; Liang, L.; Bray, G.A.; Qi, L.; Hu, F.B.; Rood, J.; Sacks, F.M.; Sun, Q. Thyroid Hormones and Changes in Body Weight and Metabolic Parameters in Response to Weight-Loss Diets: The POUNDS LOST Trial. Int. J. Obes. 2017, 41, 878-886. [CrossRef] [PubMed]

7. Delitala, A.P.; Scuteri, A.; Doria, C. Thyroid Hormone Diseases and Osteoporosis. J. Clin. Med. 2020, 9, 1034. [CrossRef] [PubMed]

8. López, M.; Varela, L.; Vázquez, M.J.; Rodríguez-Cuenca, S.; González, C.R.; Velagapudi, V.R.; Morgan, D.A.; Schoenmakers, E.; Agassandian, K.; Lage, R.; et al. Hypothalamic AMPK and Fatty Acid Metabolism Mediate Thyroid Regulation of Energy Balance. Nat. Med. 2010, 16, 1001-1008. [CrossRef] [PubMed]

9. Lowell, B.B.; Spiegelman, B.M. Towards a Molecular Understanding of Adaptive Thermogenesis. Nature 2000, 404, 652-660. [CrossRef] [PubMed]

10. Commission for Thermal Physiology of the International Union of Physiological Sciences (IUPS Thermal Commission). Glossary of Terms for Thermal Physiology: Second Edition. Pflugers Arch. 1987, 410, 567-587. [CrossRef]

11. Garretson, J.T.; Szymanski, L.A.; Schwartz, G.J.; Xue, B.; Ryu, V.; Bartness, T.J. Lipolysis Sensation by White Fat Afferent Nerves Triggers Brown Fat Thermogenesis. Mol. Metab. 2016, 5, 626-634. [CrossRef]

12. Ameka, M.; Markan, K.R.; Morgan, D.A.; BonDurant, L.D.; Idiga, S.O.; Naber, M.C.; Zhu, Z.; Zingman, L.V.; Grobe, J.L.; Rahmouni, K.; et al. Liver Derived FGF21 Maintains Core Body Temperature During Acute Cold Exposure. Sci. Rep. 2019, 9, 630. [CrossRef]

13. Arhire, L.I.; Mihalache, L.; Covasa, M. Irisin: A Hope in Understanding and Managing Obesity and Metabolic Syndrome. Front. Endocrinol. 2019, 10. [CrossRef]

14. Scheele, C.; Wolfrum, C. Brown Adipose Crosstalk in Tissue Plasticity and Human Metabolism. Endocr. Rev. 2020, 41. [CrossRef]

15. Villarroya, F.; Gavaldà-Navarro, A.; Peyrou, M.; Villarroya, J.; Giralt, M. Brown Adipokines. Handb. Exp. Pharmacol. 2019, 251, 239-256. [CrossRef]

16. Cannon, B.; Nedergaard, J. Brown Adipose Tissue: Function and Physiological Significance. Physiol. Rev. 2004, 84, 277-359. [CrossRef] [PubMed]

17. Oelkrug, R.; Polymeropoulos, E.T.; Jastroch, M. Brown Adipose Tissue: Physiological Function and Evolutionary Significance. J. Comp. Physiol. B 2015, 185, 587-606. [CrossRef]

18. Marlatt, K.L.; Ravussin, E. Brown Adipose Tissue: An Update on Recent Findings. Curr. Obes. Rep. 2017, 6, 389-396. [CrossRef] [PubMed]

19. Ricquier, D. UCP1, the Mitochondrial Uncoupling Protein of Brown Adipocyte: A Personal Contribution and a Historical Perspective. Biochimie 2017, 134, 3-8. [CrossRef]

20. Chouchani, E.T.; Kazak, L.; Spiegelman, B.M. New Advances in Adaptive Thermogenesis: UCP1 and Beyond. Cell Metab. 2019, 29, 27-37. [CrossRef] [PubMed]

21. Heeren, J.; Scheja, L. Brown Adipose Tissue and Lipid Metabolism. Curr. Opin Lipidol. 2018, 29, 180-185. [CrossRef]

22. Xiang, A.S.; Meikle, P.J.; Carey, A.L.; Kingwell, B.A. Brown Adipose Tissue and Lipid Metabolism: New Strategies for Identification of Activators and Biomarkers with Clinical Potential. Pharmacol. Ther. 2018, 192, 141-149. [CrossRef] [PubMed]

23. Jeong, J.H.; Chang, J.S.; Jo, Y.-H. Intracellular Glycolysis in Brown Adipose Tissue Is Essential for Optogenetically Induced Nonshivering Thermogenesis in Mice. Sci. Rep. 2018, 8, 6672. [CrossRef] [PubMed] 
24. Chitraju, C.; Fischer, A.W.; Farese, R.V.; Walther, T.C. Lipid Droplets in Brown Adipose Tissue Are Dispensable for Cold-Induced Thermogenesis. Cell Rep. 2020, 33, 108348. [CrossRef]

25. Panic, V.; Pearson, S.; Banks, J.; Tippetts, T.S.; Velasco-Silva, J.N.; Lee, S.; Simcox, J.; Geoghegan, G.; Bensard, C.L.; van Ry, T.; et al. Mitochondrial Pyruvate Carrier Is Required for Optimal Brown Fat Thermogenesis. eLife 2020, 9. [CrossRef]

26. Wang, Z.; Ning, T.; Song, A.; Rutter, J.; Wang, Q.A.; Jiang, L. Chronic Cold Exposure Enhances Glucose Oxidation in Brown Adipose Tissue. EMBO Rep. 2020, 21, e50085. [CrossRef]

27. Rahbani, J.F.; Roesler, A.; Hussain, M.F.; Samborska, B.; Dykstra, C.B.; Tsai, L.; Jedrychowski, M.P.; Vergnes, L.; Reue, K.; Spiegelman, B.M.; et al. Creatine Kinase B Controls Futile Creatine Cycling in Thermogenic Fat. Nature 2021, 590, 480-485. [CrossRef] [PubMed]

28. Kazak, L.; Chouchani, E.T.; Jedrychowski, M.P.; Erickson, B.K.; Shinoda, K.; Cohen, P.; Vetrivelan, R.; Lu, G.Z.; Laznik-Bogoslavski, D.; Hasenfuss, S.C.; et al. A Creatine-Driven Substrate Cycle Enhances Energy Expenditure and Thermogenesis in Beige Fat. Cell 2015, 163, 643-655. [CrossRef]

29. Ikeda, K.; Yamada, T. UCP1 Dependent and Independent Thermogenesis in Brown and Beige Adipocytes. Front. Endocrinol. 2020, 11, 498. [CrossRef]

30. Choe, S.S.; Huh, J.Y.; Hwang, I.J.; Kim, J.I.; Kim, J.B. Adipose Tissue Remodeling: Its Role in Energy Metabolism and Metabolic Disorders. Front. Endocrinol. 2016, 7. [CrossRef]

31. Pilkington, A.-C.; Paz, H.A.; Wankhade, U.D. Beige Adipose Tissue Identification and Marker Specificity-Overview. Front. Endocrinol. 2021, 12, 599134. [CrossRef] [PubMed]

32. Shao, M.; Wang, Q.A.; Song, A.; Vishvanath, L.; Busbuso, N.C.; Scherer, P.E.; Gupta, R.K. Cellular Origins of Beige Fat Cells Revisited. Diabetes 2019, 68, 1874-1885. [CrossRef] [PubMed]

33. Paulo, E.; Wang, B. Towards a Better Understanding of Beige Adipocyte Plasticity. Cells 2019, 8, 1552. [CrossRef] [PubMed]

34. Ikeda, K.; Maretich, P.; Kajimura, S. The Common and Distinct Features of Brown and Beige Adipocytes. Trends Endocrinol. Metab. 2018, 29, 191-200. [CrossRef] [PubMed]

35. Leitner, B.P.; Huang, S.; Brychta, R.J.; Duckworth, C.J.; Baskin, A.S.; McGehee, S.; Tal, I.; Dieckmann, W.; Gupta, G.; Kolodny, G.M.; et al. Mapping of Human Brown Adipose Tissue in Lean and Obese Young Men. Proc. Natl. Acad. Sci. USA 2017, 114, 8649-8654. [CrossRef]

36. Sharp, L.Z.; Shinoda, K.; Ohno, H.; Scheel, D.W.; Tomoda, E.; Ruiz, L.; Hu, H.; Wang, L.; Pavlova, Z.; Gilsanz, V.; et al. Human BAT Possesses Molecular Signatures That Resemble Beige/Brite Cells. PLoS ONE 2012, 7, e49452. [CrossRef]

37. Lidell, M.E.; Betz, M.J.; Dahlqvist Leinhard, O.; Heglind, M.; Elander, L.; Slawik, M.; Mussack, T.; Nilsson, D.; Romu, T.; Nuutila, P.; et al. Evidence for Two Types of Brown Adipose Tissue in Humans. Nat. Med. 2013, 19, 631-634. [CrossRef]

38. Chondronikola, M.; Volpi, E.; Børsheim, E.; Porter, C.; Annamalai, P.; Enerbäck, S.; Lidell, M.E.; Saraf, M.K.; Labbe, S.M.; Hurren, N.M.; et al. Brown Adipose Tissue Improves Whole-Body Glucose Homeostasis and Insulin Sensitivity in Humans. Diabetes 2014, 63, 4089-4099. [CrossRef]

39. Cypess, A.M.; Weiner, L.S.; Roberts-Toler, C.; Franquet Elía, E.; Kessler, S.H.; Kahn, P.A.; English, J.; Chatman, K.; Trauger, S.A.; Doria, A.; et al. Activation of Human Brown Adipose Tissue by a B3-Adrenergic Receptor Agonist. Cell Metab. 2015, $21,33-38$. [CrossRef]

40. van der Lans, A.A.J.J.; Hoeks, J.; Brans, B.; Vijgen, G.H.E.J.; Visser, M.G.W.; Vosselman, M.J.; Hansen, J.; Jörgensen, J.A.; Wu, J.; Mottaghy, F.M.; et al. Cold Acclimation Recruits Human Brown Fat and Increases Nonshivering Thermogenesis. J. Clin. Investig. 2013, 123, 3395-3403. [CrossRef] [PubMed]

41. Yoneshiro, T.; Aita, S.; Matsushita, M.; Kayahara, T.; Kameya, T.; Kawai, Y.; Iwanaga, T.; Saito, M. Recruited Brown Adipose Tissue as an Antiobesity Agent in Humans. J. Clin. Investig. 2013, 123, 3404-3408. [CrossRef]

42. Muzik, O.; Mangner, T.J.; Leonard, W.R.; Kumar, A.; Janisse, J.; Granneman, J.G. 15O PET Measurement of Blood Flow and Oxygen Consumption in Cold-Activated Human Brown Fat. J. Nucl. Med. 2013, 54, 523-531. [CrossRef]

43. Din, M.U.; Raiko, J.; Saari, T.; Kudomi, N.; Tolvanen, T.; Oikonen, V.; Teuho, J.; Sipilä, H.T.; Savisto, N.; Parkkola, R.; et al. Human Brown Adipose Tissue [(15)O]O2 PET Imaging in the Presence and Absence of Cold Stimulus. Eur. J. Nucl. Med. Mol. Imaging 2016, 43, 1878-1886. [CrossRef]

44. Fernández-Verdejo, R.; Marlatt, K.L.; Ravussin, E.; Galgani, J.E. Contribution of Brown Adipose Tissue to Human Energy Metabolism. Mol. Aspects Med. 2019, 68, 82-89. [CrossRef] [PubMed]

45. Pant, M.; Bal, N.C.; Periasamy, M. Sarcolipin: A Key Thermogenic and Metabolic Regulator in Skeletal Muscle. Trends Endocrinol. Metab. 2016, 27, 881-892. [CrossRef] [PubMed]

46. Periasamy, M.; Maurya, S.K.; Sahoo, S.K.; Singh, S.; Sahoo, S.K.; Reis, F.C.G.; Bal, N.C. Role of SERCA Pump in Muscle Thermogenesis and Metabolism. Compr. Physiol. 2017, 7, 879-890. [CrossRef] [PubMed]

47. Periasamy, M.; Herrera, J.L.; Reis, F.C.G. Skeletal Muscle Thermogenesis and Its Role in Whole Body Energy Metabolism. Diabetes Metab. J. 2017, 41, 327-336. [CrossRef] [PubMed]

48. Gamu, D.; Juracic, E.S.; Hall, K.J.; Tupling, A.R. The Sarcoplasmic Reticulum and SERCA: A Nexus for Muscular Adaptive Thermogenesis. Appl. Physiol. Nutr. Metab. 2020, 45, 1-10. [CrossRef] [PubMed]

49. Riley, C.L.; Dao, C.; Kenaston, M.A.; Muto, L.; Kohno, S.; Nowinski, S.M.; Solmonson, A.D.; Pfeiffer, M.; Sack, M.N.; Lu, Z.; et al. The Complementary and Divergent Roles of Uncoupling Proteins 1 and 3 in Thermoregulation. J. Physiol. 2016, 594, 7455-7464. [CrossRef] [PubMed] 
50. Pohl, E.E.; Rupprecht, A.; Macher, G.; Hilse, K.E. Important Trends in UCP3 Investigation. Front. Physiol. 2019, 10. [CrossRef] [PubMed]

51. Lim, S.; Honek, J.; Xue, Y.; Seki, T.; Cao, Z.; Andersson, P.; Yang, X.; Hosaka, K.; Cao, Y. Cold-Induced Activation of Brown Adipose Tissue and Adipose Angiogenesis in Mice. Nat. Protoc. 2012, 7, 606-615. [CrossRef]

52. Bachman, E.S.; Dhillon, H.; Zhang, C.-Y.; Cinti, S.; Bianco, A.C.; Kobilka, B.K.; Lowell, B.B. BetaAR Signaling Required for Diet-Induced Thermogenesis and Obesity Resistance. Science 2002, 297, 843-845. [CrossRef] [PubMed]

53. Himms-Hagen, J.; Hogan, S.; Zaror-Behrens, G. Increased Brown Adipose Tissue Thermogenesis in Obese (Ob/Ob) Mice Fed a Palatable Diet. Am. J. Physiol. 1986, 250, E274-E281. [CrossRef] [PubMed]

54. Rothwell, N.J.; Stock, M.J. A Role for Brown Adipose Tissue in Diet-Induced Thermogenesis. Nature 1979, 281, 31-35. [CrossRef] [PubMed]

55. Saito, M.; Matsushita, M.; Yoneshiro, T.; Okamatsu-Ogura, Y. Brown Adipose Tissue, Diet-Induced Thermogenesis, and Thermogenic Food Ingredients: From Mice to Men. Front. Endocrinol. 2020, 11. [CrossRef]

56. Lumpkin, E.A.; Caterina, M.J. Mechanisms of Sensory Transduction in the Skin. Nature 2007, 445, 858-865. [CrossRef]

57. Nakamura, K.; Morrison, S.F. A Thermosensory Pathway That Controls Body Temperature. Nat. Neurosci. 2008, $11,62-71$. [CrossRef]

58. Moran, T.H.; Norgren, R.; Crosby, R.J.; McHugh, P.R. Central and Peripheral Vagal Transport of Cholecystokinin Binding Sites Occurs in Afferent Fibers. Brain Res. 1990, 526, 95-102. [CrossRef]

59. Mönnikes, H.; Lauer, G.; Arnold, R. Peripheral Administration of Cholecystokinin Activates C-Fos Expression in the Locus Coeruleus/Subcoeruleus Nucleus, Dorsal Vagal Complex and Paraventricular Nucleus via Capsaicin-Sensitive Vagal Afferents and CCK-A Receptors in the Rat. Brain Res. 1997, 770, 277-288. [CrossRef]

60. Paschos, G.K.; Tang, S.Y.; Theken, K.N.; Li, X.; Verginadis, I.; Lekkas, D.; Herman, L.; Yan, W.; Lawson, J.; FitzGerald, G.A. Cold-Induced Browning of Inguinal White Adipose Tissue Is Independent of Adipose Tissue Cyclooxygenase-2. Cell Rep. 2018, 24, 809-814. [CrossRef]

61. Xu, Z.; You, W.; Zhou, Y.; Chen, W.; Wang, Y.; Shan, T. Cold-Induced Lipid Dynamics and Transcriptional Programs in White Adipose Tissue. BMC Biol. 2019, 17, 74. [CrossRef]

62. García-Ruiz, E.; Reynés, B.; Díaz-Rúa, R.; Ceresi, E.; Oliver, P.; Palou, A. The Intake of High-Fat Diets Induces the Acquisition of Brown Adipocyte Gene Expression Features in White Adipose Tissue. Int. J. Obes. 2015, 39, 1619-1629. [CrossRef]

63. Akagiri, S.; Naito, Y.; Ichikawa, H.; Mizushima, K.; Takagi, T.; Handa, O.; Kokura, S.; Yoshikawa, T. Bofutsushosan, an Oriental Herbal Medicine, Attenuates the Weight Gain of White Adipose Tissue and the Increased Size of Adipocytes Associated with the Increase in Their Expression of Uncoupling Protein 1 in High-Fat Diet-Fed Male KK/Ta Mice. J. Clin. Biochem. Nutr. 2008, 42, 158-166. [CrossRef]

64. Jimenez, M.; Léger, B.; Canola, K.; Lehr, L.; Arboit, P.; Seydoux, J.; Russell, A.P.; Giacobino, J.P.; Muzzin, P.; Preitner, F. Beta(1)/Beta(2)/Beta(3)-Adrenoceptor Knockout Mice Are Obese and Cold-Sensitive but Have Normal Lipolytic Responses to Fasting. FEBS Lett. 2002, 530, 37-40. [CrossRef]

65. Preite, N.Z.; do Nascimento, B.P.P.; Muller, C.R.; Américo, A.L.V.; Higa, T.S.; Evangelista, F.S.; Lancellotti, C.L.; dos Henriques, F.S.; Batista, M.L.; Bianco, A.C.; et al. Disruption of Beta3 Adrenergic Receptor Increases Susceptibility to DIO in Mouse. J. Endocrinol. 2016, 231, 259-269. [CrossRef] [PubMed]

66. Enerbäck, S.; Jacobsson, A.; Simpson, E.M.; Guerra, C.; Yamashita, H.; Harper, M.E.; Kozak, L.P. Mice Lacking Mitochondrial Uncoupling Protein Are Cold-Sensitive but Not Obese. Nature 1997, 387, 90-94. [CrossRef]

67. Feldmann, H.M.; Golozoubova, V.; Cannon, B.; Nedergaard, J. UCP1 Ablation Induces Obesity and Abolishes Diet-Induced Thermogenesis in Mice Exempt from Thermal Stress by Living at Thermoneutrality. Cell Metab. 2009, 9, 203-209. [CrossRef] [PubMed]

68. Kazak, L.; Chouchani, E.T.; Stavrovskaya, I.G.; Lu, G.Z.; Jedrychowski, M.P.; Egan, D.F.; Kumari, M.; Kong, X.; Erickson, B.K.; Szpyt, J.; et al. UCP1 Deficiency Causes Brown Fat Respiratory Chain Depletion and Sensitizes Mitochondria to Calcium Overload-Induced Dysfunction. Proc. Natl. Acad. Sci. USA 2017, 114, 7981-7986. [CrossRef] [PubMed]

69. Bianco, A.C.; Silva, J.E. Intracellular Conversion of Thyroxine to Triiodothyronine Is Required for the Optimal Thermogenic Function of Brown Adipose Tissue. J. Clin. Investig. 1987, 79, 295-300. [CrossRef]

70. Silva, J.E. The Thermogenic Effect of Thyroid Hormone and Its Clinical Implications. Ann. Intern. Med. 2003, 139, 205. [CrossRef]

71. Maushart, C.I.; Loeliger, R.; Gashi, G.; Christ-Crain, M.; Betz, M.J. Resolution of Hypothyroidism Restores Cold-Induced Thermogenesis in Humans. Thyroid 2019, 29, 493-501. [CrossRef] [PubMed]

72. Ueta, C.B.; Olivares, E.L.; Bianco, A.C. Responsiveness to Thyroid Hormone and to Ambient Temperature Underlies Differences between Brown Adipose Tissue and Skeletal Muscle Thermogenesis in a Mouse Model of Diet-Induced Obesity. Endocrinology 2011, 152, 3571-3581. [CrossRef]

73. Bianco, A.; da Conceição, R. The Deiodinase Trio and Thyroid Hormone Signaling. Methods Mol. Biol. 2018, 1801, 67-83. [CrossRef]

74. Margolis, R.N. The Nuclear Receptor Signaling Atlas: Catalyzing Understanding of Thyroid Hormone Signaling and Metabolic Control. Thyroid 2008, 18, 113-122. [CrossRef] [PubMed]

75. Minakhina, S.; Bansal, S.; Zhang, A.; Brotherton, M.; Janodia, R.; De Oliveira, V.; Tadepalli, S.; Wondisford, F.E. A Direct Comparison of Thyroid Hormone Receptor Protein Levels in Mice Provides Unexpected Insights into Thyroid Hormone Action. Thyroid 2020, 30, 1193-1204. [CrossRef] [PubMed] 
76. Flamant, F. Futures Challenges in Thyroid Hormone Signaling Research. Front. Endocrinol. 2016, 7, 58. [CrossRef]

77. Flamant, F.; Cheng, S.-Y.; Hollenberg, A.N.; Moeller, L.C.; Samarut, J.; Wondisford, F.E.; Yen, P.M.; Refetoff, S. Thyroid Hormone Signaling Pathways: Time for a More Precise Nomenclature. Endocrinology 2017, 158, 2052-2057. [CrossRef]

78. Sinha, R.; Yen, P.M. Cellular Action of Thyroid Hormone. In Endotext; Feingold, K.R., Anawalt, B., Boyce, A., Chrousos, G., de Herder, W.W., Dhatariya, K., Dungan, K., Grossman, A., Hershman, J.M., Hofland, J., et al., Eds.; MDText.com, Inc.: South Dartmouth, MA, USA, 2000.

79. Bianco, A.C.; Silva, J.E. Cold Exposure Rapidly Induces Virtual Saturation of Brown Adipose Tissue Nuclear T3 Receptors. Am. J. Physiol. 1988, 255, E496-E503. [CrossRef]

80. Silva, J.E.; Larsen, P.R. Potential of Brown Adipose Tissue Type II Thyroxine 5'-Deiodinase as a Local and Systemic Source of Triiodothyronine in Rats. J. Clin. Investig. 1985, 76, 2296-2305. [CrossRef]

81. Mohácsik, P.; Erdélyi, F.; Baranyi, M.; Botz, B.; Szabó, G.; Tóth, M.; Haltrich, I.; Helyes, Z.; Sperlágh, B.; Tóth, Z.; et al. A Transgenic Mouse Model for Detection of Tissue-Specific Thyroid Hormone Action. Endocrinology 2017, 159, 1159-1171. [CrossRef]

82. Schneider, M.J.; Fiering, S.N.; Pallud, S.E.; Parlow, A.F.; St. Germain, D.L.; Galton, V.A. Targeted Disruption of the Type 2 Selenodeiodinase Gene (DIO2) Results in a Phenotype of Pituitary Resistance to T4. Mol. Endocrinol. 2001, 15, 2137-2148. [CrossRef]

83. de Jesus, L.A.; Carvalho, S.D.; Ribeiro, M.O.; Schneider, M.; Kim, S.W.; Harney, J.W.; Larsen, P.R.; Bianco, A.C. The Type 2 Iodothyronine Deiodinase Is Essential for Adaptive Thermogenesis in Brown Adipose Tissue. J. Clin. Investig. 2001, 108, 1379-1385. [CrossRef] [PubMed]

84. Christoffolete, M.A.; Linardi, C.C.G.; de Jesus, L.; Ebina, K.N.; Carvalho, S.D.; Ribeiro, M.O.; Rabelo, R.; Curcio, C.; Martins, L.; Kimura, E.T.; et al. Mice with Targeted Disruption of the Dio2 Gene Have Cold-Induced Overexpression of the Uncoupling Protein 1 Gene but Fail to Increase Brown Adipose Tissue Lipogenesis and Adaptive Thermogenesis. Diabetes 2004, 53, 577-584. [CrossRef]

85. Castillo, M.; Hall, J.A.; Correa-Medina, M.; Ueta, C.; Kang, H.W.; Cohen, D.E.; Bianco, A.C. Disruption of Thyroid Hormone Activation in Type 2 Deiodinase Knockout Mice Causes Obesity with Glucose Intolerance and Liver Steatosis Only at Thermoneutrality. Diabetes 2011, 60, 1082-1089. [CrossRef]

86. Fischer, A.W.; Cannon, B.; Nedergaard, J. The Answer to the Question “What Is the Best Housing Temperature to Translate Mouse Experiments to Humans?" Is: Thermoneutrality. Mol. Metab. 2019, 26, 1-3. [CrossRef] [PubMed]

87. Shu, L.; Hoo, R.L.C.; Wu, X.; Pan, Y.; Lee, I.P.C.; Cheong, L.Y.; Bornstein, S.R.; Rong, X.; Guo, J.; Xu, A. A-FABP Mediates Adaptive Thermogenesis by Promoting Intracellular Activation of Thyroid Hormones in Brown Adipocytes. Nat. Commun. $2017,8,14147$. [CrossRef] [PubMed]

88. Silva, J.E.; Larsen, P.R. Adrenergic Activation of Triiodothyronine Production in Brown Adipose Tissue. Nature 1983, 305, 712-713. [CrossRef]

89. Grozovsky, R.; Ribich, S.; Rosene, M.L.; Mulcahey, M.A.; Huang, S.A.; Patti, M.E.; Bianco, A.C.; Kim, B.W. Type 2 Deiodinase Expression Is Induced by Peroxisomal Proliferator-Activated Receptor-Gamma Agonists in Skeletal Myocytes. Endocrinology 2009, 150, 1976-1983. [CrossRef]

90. Hosoi, Y.; Murakami, M.; Mizuma, H.; Ogiwara, T.; Imamura, M.; Mori, M. Expression and Regulation of Type II Iodothyronine Deiodinase in Cultured Human Skeletal Muscle Cells. J. Clin. Endocrinol. Metab. 1999, 84, 3293-3300. [CrossRef]

91. Salvatore, D.; Bartha, T.; Harney, J.W.; Larsen, P.R. Molecular Biological and Biochemical Characterization of the Human Type 2 Selenodeiodinase. Endocrinology 1996, 137, 3308-3315. [CrossRef]

92. Fonseca, T.L.; Werneck-De-Castro, J.P.; Castillo, M.; Bocco, B.M.L.C.; Fernandes, G.W.; McAninch, E.A.; Ignacio, D.L.; Moises, C.C.S.; Ferreira, A.R.; Gereben, B.; et al. Tissue-Specific Inactivation of Type 2 Deiodinase Reveals Multilevel Control of Fatty Acid Oxidation by Thyroid Hormone in the Mouse. Diabetes 2014, 63, 1594-1604. [CrossRef] [PubMed]

93. Carmody, C.; Ogawa-Wong, A.N.; Martin, C.; Luongo, C.; Zuidwijk, M.; Sager, B.; Petersen, T.; Roginski Guetter, A.; Janssen, R.; Wu, E.Y.; et al. A Global Loss of Dio2 Leads to Unexpected Changes in Function and Fiber Types of Slow Skeletal Muscle in Male Mice. Endocrinology 2019, 160, 1205-1222. [CrossRef] [PubMed]

94. Gonzalez-Hurtado, E.; Lee, J.; Choi, J.; Wolfgang, M.J. Fatty Acid Oxidation Is Required for Active and Quiescent Brown Adipose Tissue Maintenance and Thermogenic Programing. Mol. Metab. 2017, 7, 45-56. [CrossRef] [PubMed]

95. Lee, J.; Ellis, J.M.; Wolfgang, M.J. Adipose Fatty Acid Oxidation Is Required for Thermogenesis and Potentiates Oxidative Stress Induced Inflammation. Cell Rep. 2015, 10, 266-279. [CrossRef] [PubMed]

96. Flamant, F.; Samarut, J. Thyroid Hormone Receptors: Lessons from Knockout and Knock-in Mutant Mice. Trends Endocrinol. Metab. 2003, 14, 85-90. [CrossRef]

97. Gauthier, K.; Plateroti, M.; Harvey, C.B.; Williams, G.R.; Weiss, R.E.; Refetoff, S.; Willott, J.F.; Sundin, V.; Roux, J.P.; Malaval, L.; et al. Genetic Analysis Reveals Different Functions for the Products of the Thyroid Hormone Receptor Alpha Locus. Mol. Cell Biol. 2001, 21, 4748-4760. [CrossRef]

98. Golozoubova, V.; Gullberg, H.; Matthias, A.; Cannon, B.; Vennström, B.; Nedergaard, J. Depressed Thermogenesis but Competent Brown Adipose Tissue Recruitment in Mice Devoid of All Hormone-Binding Thyroid Hormone Receptors. Mol. Endocrinol. 2004, 18, 384-401. [CrossRef]

99. Marrif, H.; Schifman, A.; Stepanyan, Z.; Gillis, M.-A.; Calderone, A.; Weiss, R.E.; Samarut, J.; Silva, J.E. Temperature Homeostasis in Transgenic Mice Lacking Thyroid Hormone Receptor-Alpha Gene Products. Endocrinology 2005, 146, 2872-2884. [CrossRef] 
100. Kaneshige, M.; Kaneshige, K.; Zhu, X.; Dace, A.; Garrett, L.; Carter, T.A.; Kazlauskaite, R.; Pankratz, D.G.; Wynshaw-Boris, A.; Refetoff, S.; et al. Mice with a Targeted Mutation in the Thyroid Hormone $\beta$ Receptor Gene Exhibit Impaired Growth and Resistance to Thyroid Hormone. Proc. Natl. Acad. Sci. USA 2000, 97, 13209-13214. [CrossRef]

101. Ribeiro, M.O.; Bianco, S.D.C.; Kaneshige, M.; Schultz, J.J.; Cheng, S.; Bianco, A.C.; Brent, G.A. Expression of Uncoupling Protein 1 in Mouse Brown Adipose Tissue Is Thyroid Hormone Receptor- $\beta$ Isoform Specific and Required for Adaptive Thermogenesis. Endocrinology 2010, 151, 432-440. [CrossRef]

102. Chiellini, G.; Apriletti, J.W.; Yoshihara, H.A.; Baxter, J.D.; Ribeiro, R.C.; Scanlan, T.S. A High-Affinity Subtype-Selective Agonist Ligand for the Thyroid Hormone Receptor. Chem. Biol. 1998, 5, 299-306. [CrossRef]

103. Nedergaard, J.; Dicker, A.; Cannon, B. The Interaction between Thyroid and Brown-Fat Thermogenesis. Central or Peripheral Effects? Ann. N. Y. Acad. Sci. 1997, 813, 712-717. [CrossRef]

104. Bernardis, L.L.; Goldman, J.K. Origin of Endocrine-Metabolic Changes in the Weanling Rat Ventromedial Syndrome. J. Neurosci. Res. 1976, 2, 91-116. [CrossRef] [PubMed]

105. Perkins, M.N.; Rothwell, N.J.; Stock, M.J.; Stone, T.W. Activation of Brown Adipose Tissue Thermogenesis by the Ventromedial Hypothalamus. Nature 1981, 289, 401-402. [CrossRef] [PubMed]

106. Lechan, R.M.; Fekete, C. Role of Thyroid Hormone Deiodination in the Hypothalamus. Thyroid 2005, 15, 883-897. [CrossRef]

107. Mayerl, S.; Müller, J.; Bauer, R.; Richert, S.; Kassmann, C.M.; Darras, V.M.; Buder, K.; Boelen, A.; Visser, T.J.; Heuer, H. Transporters MCT8 and OATP1C1 Maintain Murine Brain Thyroid Hormone Homeostasis. J. Clin. Investig. 2014, 124, 1987-1999. [CrossRef]

108. Wallis, K.; Dudazy, S.; van Hogerlinden, M.; Nordström, K.; Mittag, J.; Vennström, B. The Thyroid Hormone Receptor Alpha1 Protein Is Expressed in Embryonic Postmitotic Neurons and Persists in Most Adult Neurons. Mol. Endocrinol. 2010, 24, $1904-1916$. [CrossRef]

109. Hameed, S.; Patterson, M.; Dhillo, W.S.; Rahman, S.A.; Ma, Y.; Holton, C.; Gogakos, A.; Yeo, G.S.H.; Lam, B.Y.H.; Polex-Wolf, J.; et al. Thyroid Hormone Receptor Beta in the Ventromedial Hypothalamus Is Essential for the Physiological Regulation of Food Intake and Body Weight. Cell Rep. 2017, 19, 2202-2209. [CrossRef] [PubMed]

110. Whittle, A.J.; Carobbio, S.; Martins, L.; Slawik, M.; Hondares, E.; Vázquez, M.J.; Morgan, D.; Csikasz, R.I.; Gallego, R.; RodriguezCuenca, S.; et al. BMP8B Increases Brown Adipose Tissue Thermogenesis through Both Central and Peripheral Actions. Cell 2012, 149, 871-885. [CrossRef] [PubMed]

111. Lockie, S.H.; Heppner, K.M.; Chaudhary, N.; Chabenne, J.R.; Morgan, D.A.; Veyrat-Durebex, C.; Ananthakrishnan, G.; RohnerJeanrenaud, F.; Drucker, D.J.; DiMarchi, R.; et al. Direct Control of Brown Adipose Tissue Thermogenesis by Central Nervous System Glucagon-like Peptide-1 Receptor Signaling. Diabetes 2012, 61, 2753-2762. [CrossRef]

112. Martínez de Morentin, P.B.; González-García, I.; Martins, L.; Lage, R.; Fernández-Mallo, D.; Martínez-Sánchez, N.; Ruíz-Pino, F.; Liu, J.; Morgan, D.A.; Pinilla, L.; et al. Estradiol Regulates Brown Adipose Tissue Thermogenesis via Hypothalamic AMPK. Cell Metab. 2014, 20, 41-53. [CrossRef]

113. Tanida, M.; Yamamoto, N.; Shibamoto, T.; Rahmouni, K. Involvement of Hypothalamic AMP-Activated Protein Kinase in Leptin-Induced Sympathetic Nerve Activation. PLoS ONE 2013, 8, e56660. [CrossRef]

114. Martínez-Sánchez, N.; Seoane-Collazo, P.; Contreras, C.; Varela, L.; Villarroya, J.; Rial-Pensado, E.; Buqué, X.; Aurrekoetxea, I.; Delgado, T.C.; Vázquez-Martínez, R.; et al. Hypothalamic AMPK-ER Stress-JNK1 Axis Mediates the Central Actions of Thyroid Hormones on Energy Balance. Cell Metab. 2017, 26, 212-229.e12. [CrossRef] [PubMed]

115. Contreras, C.; González-García, I.; Seoane-Collazo, P.; Martínez-Sánchez, N.; Liñares-Pose, L.; Rial-Pensado, E.; Fernø, J.; TenaSempere, M.; Casals, N.; Diéguez, C.; et al. Reduction of Hypothalamic Endoplasmic Reticulum Stress Activates Browning of White Fat and Ameliorates Obesity. Diabetes 2017, 66, 87-99. [CrossRef] [PubMed]

116. Zhang, Z.; Bisschop, P.H.; Foppen, E.; van Beeren, H.C.; Kalsbeek, A.; Boelen, A.; Fliers, E. A Model for Chronic, Intrahypothalamic Thyroid Hormone Administration in Rats. J. Endocrinol. 2016, 229, 37-45. [CrossRef] [PubMed]

117. Zhang, Z.; Foppen, E.; Su, Y.; Bisschop, P.H.; Kalsbeek, A.; Fliers, E.; Boelen, A. Metabolic Effects of Chronic T3 Administration in the Hypothalamic Paraventricular and Ventromedial Nucleus in Male Rats. Endocrinology 2016, 157, 4076-4085. [CrossRef]

118. Bachman, E.S.; Hampton, T.G.; Dhillon, H.; Amende, I.; Wang, J.; Morgan, J.P.; Hollenberg, A.N. The Metabolic and Cardiovascular Effects of Hyperthyroidism Are Largely Independent of Beta-Adrenergic Stimulation. Endocrinology 2004, 145, $2767-2774$. [CrossRef]

119. Morte, B.; Bernal, J. Thyroid Hormone Action: Astrocyte-Neuron Communication. Front. Endocrinol. 2014, 5. [CrossRef] [PubMed]

120. Villarroya, F.; Cereijo, R.; Villarroya, J.; Gavaldà-Navarro, A.; Giralt, M. Toward an Understanding of How Immune Cells Control Brown and Beige Adipobiology. Cell Metab. 2018, 27, 954-961. [CrossRef] [PubMed]

121. Villicev, C.M.; Freitas, F.R.S.; Aoki, M.S.; Taffarel, C.; Scanlan, T.S.; Moriscot, A.S.; Ribeiro, M.O.; Bianco, A.C.; Gouveia, C.H.A. Thyroid Hormone Receptor Beta-Specific Agonist GC-1 Increases Energy Expenditure and Prevents Fat-Mass Accumulation in Rats. J. Endocrinol. 2007, 193, 21-29. [CrossRef] [PubMed]

122. Lin, J.Z.; Martagón, A.J.; Cimini, S.L.; Gonzalez, D.D.; Tinkey, D.W.; Biter, A.; Baxter, J.D.; Webb, P.; Gustafsson, J.-Å.; Hartig, S.M.; et al. Pharmacological Activation of Thyroid Hormone Receptors Elicits a Functional Conversion of White to Brown Fat. Cell Rep. 2015, 13, 1528-1537. [CrossRef] 
123. Johann, K.; Cremer, A.L.; Fischer, A.W.; Heine, M.; Pensado, E.R.; Resch, J.; Nock, S.; Virtue, S.; Harder, L.; Oelkrug, R.; et al. Thyroid-Hormone-Induced Browning of White Adipose Tissue Does Not Contribute to Thermogenesis and Glucose Consumption. Cell Rep. 2019, 27, 3385-3400.e3. [CrossRef]

124. Martínez-Sánchez, N.; Moreno-Navarrete, J.M.; Contreras, C.; Rial-Pensado, E.; Fernø, J.; Nogueiras, R.; Diéguez, C.; FernándezReal, J.-M.; López, M. Thyroid Hormones Induce Browning of White Fat. J. Endocrinol. 2016, 232, 351-362. [CrossRef] [PubMed]

125. Alvarez-Crespo, M.; Csikasz, R.I.; Martínez-Sánchez, N.; Diéguez, C.; Cannon, B.; Nedergaard, J.; López, M. Essential Role of UCP1 Modulating the Central Effects of Thyroid Hormones on Energy Balance. Mol. Metab. 2016, 5, 271-282. [CrossRef]

126. Bamshad, M.; Aoki, V.T.; Adkison, M.G.; Warren, W.S.; Bartness, T.J. Central Nervous System Origins of the Sympathetic Nervous System Outflow to White Adipose Tissue. Am. J. Physiol. 1998, 275, R291-R299. [CrossRef]

127. Bamshad, M.; Song, C.K.; Bartness, T.J. CNS Origins of the Sympathetic Nervous System Outflow to Brown Adipose Tissue. Am. J. Physiol. 1999, 276, R1569-R1578. [CrossRef]

128. Weiner, J.; Kranz, M.; Klöting, N.; Kunath, A.; Steinhoff, K.; Rijntjes, E.; Köhrle, J.; Zeisig, V.; Hankir, M.; Gebhardt, C.; et al. Thyroid Hormone Status Defines Brown Adipose Tissue Activity and Browning of White Adipose Tissues in Mice. Sci. Rep. 2016, 6, 38124. [CrossRef] [PubMed]

129. Dehvari, N.; Sato, M.; Bokhari, M.H.; Kalinovich, A.; Ham, S.; Gao, J.; Nguyen, H.T.M.; Whiting, L.; Mukaida, S.; Merlin, J.; et al. The Metabolic Effects of Mirabegron Are Mediated Primarily by B3 -Adrenoceptors. Pharmacol. Res. Perspect. 2020, 8 , e00643. [CrossRef] [PubMed]

130. Nomura, E.; Toyoda, N.; Harada, A.; Nishimura, K.; Ukita, C.; Morimoto, S.; Kosaki, A.; Iwasaka, T.; Nishikawa, M. Type 2 Iodothyronine Deiodinase Is Expressed in Human Preadipocytes. Thyroid 2011, 21, 305-310. [CrossRef]

131. Lee, J.-Y.; Takahashi, N.; Yasubuchi, M.; Kim, Y.-I.; Hashizaki, H.; Kim, M.-J.; Sakamoto, T.; Goto, T.; Kawada, T. Triiodothyronine Induces UCP-1 Expression and Mitochondrial Biogenesis in Human Adipocytes. Am. J. Physiol. Cell Physiol. 2012, 302, C463-C472. [CrossRef]

132. de Oliveira, M.; Mathias, L.S.; Rodrigues, B.M.; Mariani, B.G.; Graceli, J.B.; De Sibio, M.T.; Castro Olimpio, R.M.; Fontes Moretto, F.C.; Deprá, I.C.; Nogueira, C.R. The Roles of Triiodothyronine and Irisin in Improving the Lipid Profile and Directing the Browning of Human Adipose Subcutaneous Cells. Mol. Cell Endocrinol. 2020, 506, 110744. [CrossRef]

133. Dittner, C.; Lindsund, E.; Cannon, B.; Nedergaard, J. At Thermoneutrality, Acute Thyroxine-Induced Thermogenesis and Pyrexia Are Independent of UCP1. Mol. Metab. 2019, 25, 20-34. [CrossRef] [PubMed]

134. Ikeda, K.; Kang, Q.; Yoneshiro, T.; Camporez, J.P.; Maki, H.; Homma, M.; Shinoda, K.; Chen, Y.; Lu, X.; Maretich, P.; et al. UCP1-Independent Signaling Involving SERCA2b-Mediated Calcium Cycling Regulates Beige Fat Thermogenesis and Systemic Glucose Homeostasis. Nat. Med. 2017, 23, 1454-1465. [CrossRef] [PubMed]

135. Kazak, L.; Chouchani, E.T.; Lu, G.Z.; Jedrychowski, M.P.; Bare, C.J.; Mina, A.I.; Kumari, M.; Zhang, S.; Vuckovic, I.; LaznikBogoslavski, D.; et al. Genetic Depletion of Adipocyte Creatine Metabolism Inhibits Diet-Induced Thermogenesis and Drives Obesity. Cell Metab. 2017, 26, 693. [CrossRef] [PubMed]

136. Steinhoff, K.G.; Krause, K.; Linder, N.; Rullmann, M.; Volke, L.; Gebhardt, C.; Busse, H.; Stumvoll, M.; Blüher, M.; Sabri, O.; et al. Effects of Hyperthyroidism on Adipose Tissue Activity and Distribution in Adults. Thyroid 2021, 31, 519-527. [CrossRef] [PubMed]

137. Mitchell, C.S.; Savage, D.B.; Dufour, S.; Schoenmakers, N.; Murgatroyd, P.; Befroy, D.; Halsall, D.; Northcott, S.; Raymond-Barker, P.; Curran, S.; et al. Resistance to Thyroid Hormone Is Associated with Raised Energy Expenditure, Muscle Mitochondrial Uncoupling, and Hyperphagia. J. Clin. Investig. 2010, 120, 1345-1354. [CrossRef]

138. Nicolaisen, T.S.; Klein, A.B.; Dmytriyeva, O.; Lund, J.; Ingerslev, L.R.; Fritzen, A.M.; Carl, C.S.; Lundsgaard, A.-M.; Frost, M.; Ma, T.; et al. Thyroid Hormone Receptor $\alpha$ in Skeletal Muscle Is Essential for T3-Mediated Increase in Energy Expenditure. FASEB J. 2020, 34, 15480-15491. [CrossRef]

139. Miniou, P.; Tiziano, D.; Frugier, T.; Roblot, N.; Le Meur, M.; Melki, J. Gene Targeting Restricted to Mouse Striated Muscle Lineage. Nucleic Acids Res. 1999, 27, e27. [CrossRef]

140. Quignodon, L.; Vincent, S.; Winter, H.; Samarut, J.; Flamant, F. A Point Mutation in the Activation Function 2 Domain of Thyroid Hormone Receptor A1 Expressed after CRE-Mediated Recombination Partially Recapitulates Hypothyroidism. Mol. Endocrinol. 2007, 21, 2350-2360. [CrossRef]

141. Autry, J.M.; Thomas, D.D.; Espinoza-Fonseca, L.M. Sarcolipin Promotes Uncoupling of the SERCA Ca2+ Pump by Inducing a Structural Rearrangement in the Energy-Transduction Domin. Biochemistry 2016, 55, 6083-6086. [CrossRef]

142. Bal, N.C.; Maurya, S.K.; Sopariwala, D.H.; Sahoo, S.K.; Gupta, S.C.; Shaikh, S.A.; Pant, M.; Rowland, L.A.; Bombardier, E.; Goonasekera, S.A.; et al. Sarcolipin Is a Newly Identified Regulator of Muscle-Based Thermogenesis in Mammals. Nat. Med. 2012, 18, 1575-1579. [CrossRef]

143. Werneck-de-Castro, J.P.; Fonseca, T.L.; Ignacio, D.L.; Fernandes, G.W.; Andrade-Feraud, C.M.; Lartey, L.J.; Ribeiro, M.B.; Ribeiro, M.O.; Gereben, B.; Bianco, A.C. Thyroid Hormone Signaling in Male Mouse Skeletal Muscle Is Largely Independent of D2 in Myocytes. Endocrinology 2015, 156, 3842-3852. [CrossRef] [PubMed]

144. Feng, X.; Jiang, Y.; Meltzer, P.; Yen, P.M. Thyroid Hormone Regulation of Hepatic Genes in Vivo Detected by Complementary DNA Microarray. Mol. Endocrinol. 2000, 14, 947-955. [CrossRef] 
145. Santiago, L.A.; Santiago, D.A.; Faustino, L.C.; Cordeiro, A.; Lisboa, P.C.; Wondisford, F.E.; Pazos-Moura, C.C.; Ortiga-Carvalho, T.M. The $\Delta 337 \mathrm{~T}$ Mutation on the TR $\beta$ Causes Alterations in Growth, Adiposity, and Hepatic Glucose Homeostasis in Mice. J. Endocrinol. 2011, 211, 39-46. [CrossRef] [PubMed]

146. Jornayvaz, F.R.; Lee, H.-Y.; Jurczak, M.J.; Alves, T.C.; Guebre-Egziabher, F.; Guigni, B.A.; Zhang, D.; Samuel, V.T.; Silva, J.E.; Shulman, G.I. Thyroid Hormone Receptor- $\alpha$ Gene Knockout Mice Are Protected from Diet-Induced Hepatic Insulin Resistance. Endocrinology 2012, 153, 583-591. [CrossRef]

147. Ramadoss, P.; Abraham, B.J.; Tsai, L.; Zhou, Y.; Costa-e-Sousa, R.H.; Ye, F.; Bilban, M.; Zhao, K.; Hollenberg, A.N. Novel Mechanism of Positive versus Negative Regulation by Thyroid Hormone Receptor B1 (TR $\beta 1$ ) Identified by Genome-Wide Profiling of Binding Sites in Mouse Liver. J. Biol. Chem. 2014, 289, 1313-1328. [CrossRef]

148. Klieverik, L.P.; Sauerwein, H.P.; Ackermans, M.T.; Boelen, A.; Kalsbeek, A.; Fliers, E. Effects of Thyrotoxicosis and Selective Hepatic Autonomic Denervation on Hepatic Glucose Metabolism in Rats. Am. J. Physiol. Endocrinol. Metab. 2008, 294, E513-E520. [CrossRef] [PubMed]

149. Klieverik, L.P.; Janssen, S.F.; van Riel, A.; Foppen, E.; Bisschop, P.H.; Serlie, M.J.; Boelen, A.; Ackermans, M.T.; Sauerwein, H.P.; Fliers, E.; et al. Thyroid Hormone Modulates Glucose Production via a Sympathetic Pathway from the Hypothalamic Paraventricular Nucleus to the Liver. Proc. Natl. Acad. Sci. USA 2009, 106, 5966-5971. [CrossRef]

150. Mai, W.; Janier, M.F.; Allioli, N.; Quignodon, L.; Chuzel, T.; Flamant, F.; Samarut, J. Thyroid Hormone Receptor Alpha Is a Molecular Switch of Cardiac Function between Fetal and Postnatal Life. Proc. Natl. Acad. Sci. USA 2004, 101, 10332-10337. [CrossRef] [PubMed]

151. Hirose, K.; Payumo, A.Y.; Cutie, S.; Hoang, A.; Zhang, H.; Guyot, R.; Lunn, D.; Bigley, R.B.; Yu, H.; Wang, J.; et al. Evidence for Hormonal Control of Heart Regenerative Capacity during Endothermy Acquisition. Science 2019, 364, 184-188. [CrossRef] [PubMed]

152. Pachucki, J.; Hopkins, J.; Peeters, R.; Tu, H.; Carvalho, S.D.; Kaulbach, H.; Abel, E.D.; Wondisford, F.E.; Ingwall, J.S.; Larsen, P.R. Type 2 Iodothyronin Deiodinase Transgene Expression in the Mouse Heart Causes Cardiac-Specific Thyrotoxicosis. Endocrinology 2001, 142, 13-20. [CrossRef]

153. Vujovic, M.; Nordström, K.; Gauthier, K.; Flamant, F.; Visser, T.J.; Vennström, B.; Mittag, J. Interference of a Mutant Thyroid Hormone Receptor Alpha1 with Hepatic Glucose Metabolism. Endocrinology 2009, 150, 2940-2947. [CrossRef] [PubMed]

154. Mittag, J.; Davis, B.; Vujovic, M.; Arner, A.; Vennström, B. Adaptations of the Autonomous Nervous System Controlling Heart Rate Are Impaired by a Mutant Thyroid Hormone Receptor-Alpha1. Endocrinology 2010, 151, 2388-2395. [CrossRef] [PubMed]

155. Goldman, M.; Dratman, M.B.; Crutchfield, F.L.; Jennings, A.S.; Maruniak, J.A.; Gibbons, R. Intrathecal Triiodothyronine Administration Causes Greater Heart Rate Stimulation in Hypothyroid Rats than Intravenously Delivered Hormone. Evidence for a Central Nervous System Site of Thyroid Hormone Action. J. Clin. Investig. 1985, 76, 1622-1625. [CrossRef] [PubMed]

156. Schwartz, H.L.; Strait, K.A.; Ling, N.C.; Oppenheimer, J.H. Quantitation of Rat Tissue Thyroid Hormone Binding Receptor Isoforms by Immunoprecipitation of Nuclear Triiodothyronine Binding Capacity. J. Biol. Chem. 1992, 267, 11794-11799. [CrossRef]

157. Swanson, E.A.; Gloss, B.; Belke, D.D.; Kaneshige, M.; Cheng, S.-Y.; Dillmann, W.H. Cardiac Expression and Function of Thyroid Hormone Receptor Beta and Its PV Mutant. Endocrinology 2003, 144, 4820-4825. [CrossRef]

158. Bates, J.M.; St Germain, D.L.; Galton, V.A. Expression Profiles of the Three Iodothyronine Deiodinases, D1, D2, and D3, in the Developing Rat. Endocrinology 1999, 140, 844-851. [CrossRef]

159. Kim, H.; Kim, M.; Im, S.-K.; Fang, S. Mouse Cre-LoxP System: General Principles to Determine Tissue-Specific Roles of Target Genes. Lab Anim. Res. 2018, 34, 147-159. [CrossRef]

160. Tinnikov, A.; Nordström, K.; Thorén, P.; Kindblom, J.M.; Malin, S.; Rozell, B.; Adams, M.; Rajanayagam, O.; Pettersson, S.; Ohlsson, C.; et al. Retardation of Post-Natal Development Caused by a Negatively Acting Thyroid Hormone Receptor Alpha1. EMBO J. 2002, 21, 5079-5087. [CrossRef]

161. Gouveia, C.H.A.; Miranda-Rodrigues, M.; Martins, G.M.; Neofiti-Papi, B. Thyroid Hormone and Skeletal Development. Vitam Horm. 2018, 106, 383-472. [CrossRef] [PubMed]

162. Prezioso, G.; Giannini, C.; Chiarelli, F. Effect of Thyroid Hormones on Neurons and Neurodevelopment. Horm. Res. Paediatr. 2018, 90, 73-81. [CrossRef] [PubMed]

163. Hall, J.A.; Ribich, S.; Christoffolete, M.A.; Simovic, G.; Correa-Medina, M.; Patti, M.E.; Bianco, A.C. Absence of Thyroid Hormone Activation during Development Underlies a Permanent Defect in Adaptive Thermogenesis. Endocrinology 2010, 151, 4573-4582. [CrossRef] [PubMed]

164. Bianco, A.C.; Carvalho, S.D.; Carvalho, C.R.; Rabelo, R.; Moriscot, A.S. Thyroxine 5'-Deiodination Mediates NorepinephrineInduced Lipogenesis in Dispersed Brown Adipocytes. Endocrinology 1998, 139, 571-578. [CrossRef]

165. Negron, S.G.; Ercan-Sencicek, A.G.; Freed, J.; Walters, M.; Lin, Z. Both Proliferation and Lipogenesis of Brown Adipocytes Contribute to Postnatal Brown Adipose Tissue Growth in Mice. Sci. Rep. 2020, 10, 20335. [CrossRef]

166. Saunders, T.L. Inducible Transgenic Mouse Models. Methods Mol. Biol. 2011, 693, 103-115. [CrossRef] [PubMed]

167. Brocard, J.; Warot, X.; Wendling, O.; Messaddeq, N.; Vonesch, J.L.; Chambon, P.; Metzger, D. Spatio-Temporally Controlled Site-Specific Somatic Mutagenesis in the Mouse. Proc. Natl. Acad. Sci. USA 1997, 94, 14559-14563. [CrossRef]

168. Shoemaker, T.J.; Kono, T.; Mariash, C.N.; Evans-Molina, C. Thyroid Hormone Analogues for the Treatment of Metabolic Disorders: New Potential for Unmet Clinical Needs? Endocr. Pract. 2012, 18, 954-964. [CrossRef] 
169. Finan, B.; Yang, B.; Ottaway, N.; Stemmer, K.; Müller, T.D.; Yi, C.-X.; Habegger, K.; Schriever, S.C.; García-Cáceres, C.; Kabra, D.G.; et al. Targeted Estrogen Delivery Reverses the Metabolic Syndrome. Nat. Med. 2012, 18, 1847-1856. [CrossRef]

170. Campbell, J.E.; Drucker, D.J. Pharmacology, Physiology, and Mechanisms of Incretin Hormone Action. Cell Metab. 2013, 17, 819-837. [CrossRef]

171. Finan, B.; Clemmensen, C.; Zhu, Z.; Stemmer, K.; Gauthier, K.; Müller, L.; De Angelis, M.; Moreth, K.; Neff, F.; Perez-Tilve, D.; et al. Chemical Hybridization of Glucagon and Thyroid Hormone Optimizes Therapeutic Impact for Metabolic Disease. Cell 2016, 167, 843-857.e14. [CrossRef]

172. Svoboda, M.; Tastenoy, M.; Vertongen, P.; Robberecht, P. Relative Quantitative Analysis of Glucagon Receptor MRNA in Rat Tissues. Mol. Cell Endocrinol. 1994, 105, 131-137. [CrossRef] 